\title{
Surveys and Predicted Distribution Models for Land Mollusks on USFS Northern Region Lands: 2007
}

Prepared for:

USDA Forest Service, Northern Region

Prepared by:

Paul Hendricks, Bryce Maxell, Susan Lenard and Coburn Currier

Montana Natural Heritage Program a cooperative program of the

Montana State Library and the University of Montana

April 2008

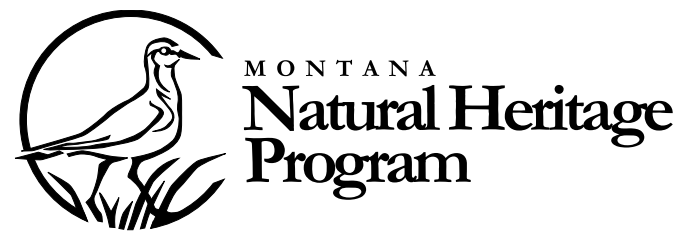





\title{
Surveys and Predicted Distribution Models for Land Mollusks on USFS Northern Region Lands: 2007
}

\author{
Prepared for: \\ USDA Forest Service, Northern Region \\ P. O. Box 7669 \\ Missoula, MT 59807
}

Agreement Number:

05-CS-11015600-033

Prepared by:

Paul Hendricks, Bryce Maxell, Susan Lenard and Coburn Currier

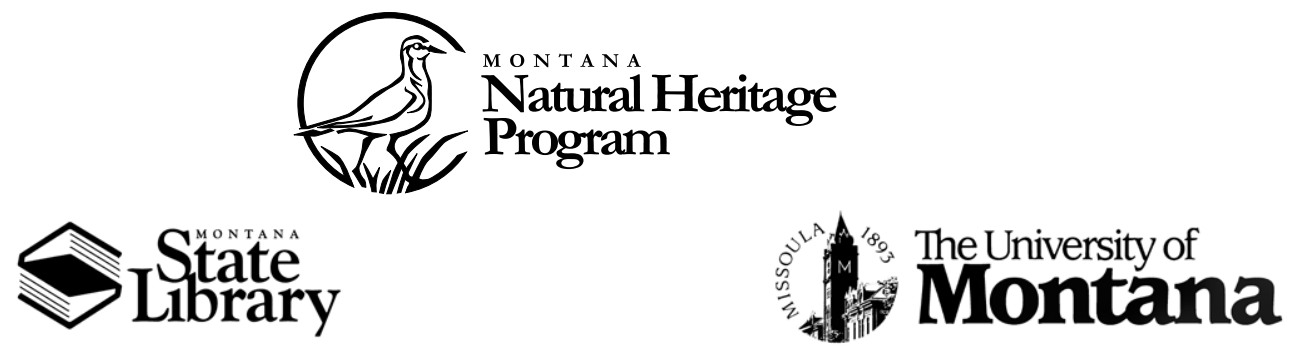

(C) 2008 Montana Natural Heritage Program

P.O. Box $201800 \bullet 1515$ East Sixth Avenue • Helena, MT 59620-1800 • 406-444-5354 
This document should be cited as follows:

Hendricks, P., B. A. Maxell, S. Lenard and C. Currier. 2008. Surveys and Predicted Distribution Models for Land Mollusks on USFS Northern Region Lands: 2007. A report to the USDA Forest Service, Northern Region. Montana Natural Heritage Program, Helena, MT. 12 pp. plus appendices. 


\section{Executive Summary}

The Northern Region of the U.S. Forest Service (USFS Region 1) provides habitat for a number of land mollusk species that are endemic to the Northern Rocky Mountains, as well as several others that are restricted to the Pacific Northwest with disjunct populations in northern Idaho and northwestern Montana. The goal of this inventory project, which began in 2005, was to fill species distribution gaps, test survey methods, and collect data for development of predictive distribution models.

Using the NatureServe website and prior reports as a starting point, we compiled a list of 29 land snail taxa within the U.S. Forest Service Northern Region that were globally ranked in 2005 as G1G3 or T1-T3, thereby meeting USFS Species of Concern (SOC) criteria. Two additional snail taxa were included with global ranks of G5 and state ranks S1-S2, thereby meeting criteria for USFS Species of Interest (SOI). We also compiled a list of eight slug taxa ranked in 2005 as G1-G3, and three additional slug taxa ranked G4-G5 and S1-S2, again meeting the respective USFS criteria for SOC or SOI. Nineteen of these SOC/SOI species (11 snails, 8 slugs) have been documented in Montana as of 2007 .

Montana Natural Heritage Program surveys in 2005 included lands in both Idaho and Montana; in 2006 and 2007 they were restricted to Montana. This report presents results of the 2007 surveys which focused on gathering additional distribution data to aid in the development of predictive distribution models and maps. We conducted a total of 34 site surveys on National Forest units in Montana, primarily targeting areas with highest expected diversity of SOC and SOI taxa but also areas where prior surveys were lacking; these were mostly (but not exclusively) west of the Continental Divide. Site surveys were distributed on the Montana Forests as follows: Kootenai (16), Lewis \& Clark (8), and Lolo (10).

We found SOC and/or SOI taxa at 55.9\% (19) of the sites surveyed, and documented a total of 38 locations for nine SOC taxa and two SOI taxa during our 2007 surveys. These taxa included: Alpine Mountainsnail Oreohelix alpina (1 site), Carinate Mountainsnail Oreohelix elrodi (1 site), Humped Coin Polygyrella polygyrella (1 site), Fir Pinwheel Radiodiscus abietum (6 sites), Pale Jumping-slug Hemphillia camelus (4 sites), Marbled Jumping-slug Hemphillia danielsi (1 site), Magnum Mantleslug Magnipelta mycophaga (4 sites), Pygmy Slug Kootenaia burkei (9 sites), Smoky Taildropper Prophysaon humile (6 sites), Lyre Mantleslug Udosarx lyrata (1 site), and Sheathed Slug Zacoleus idahoensis (4 sites). Most were found west of the Continental Divide in mesic forest habitats (e.g., western redcedar, western hemlock, mesic Douglas-fir, grand fir), although the two species of mountainsnail (Oreohelix) were from exposed rocky terrain above treeline on the Scapegoat Plateau just east of the Continental Divide. We also collected distribution data on 19 additional non-SOC/SOI species as we encountered them during our surveys.

We collected new locations for two slug SOCs that were found in Montana for the first time during our 2005 surveys: Pale Jumping-slug and Pygmy Slug. Our 2007 surveys also added several new Montana locations for a third slug SOC, Smoky Taildropper, which was documented in Montana only once prior to 2004. Several SOC snails and slugs were found at new locations during the 2005-2006 surveys, and five Global and State Ranks were reduced as a result; additional rank changes may occur as a result of the 2007 surveys.

Predicted species distribution models were developed at $90 \mathrm{~m}$ pixel resolution, using our point location data and 11 environmental data layers chosen for their assumed relationship to land snail requirements. Model output indicates that the greatest number of gaps in known species ranges (especially Species of Concern) may be filled in with additional surveys focused on portions of northwestern Montana, the Bitterroot Mountains in Mineral and Ravalli Counties, Beaverhead, Madison, and Silver Bow Counties, and portions of the island mountain ranges in eastern Montana. In addition to these gaps, a summary of elevations 
on U.S. Forest Service lands in Montana and elevations of mollusk survey locations in 20052007 indicates that high elevation sites have been under-sampled. We intend to field-test the predictive distribution models with surveys focused on these regions during the 2008 field season. 


\section{ACKNOWLedgements}

Fred Samson (USFS) recognized the need to address invertebrates in the Forest planning process, appreciating the extremely limited information available for management decision-making, and promoted the project through the USFS Regional Inventory and Monitoring (RIM) program. Skip Kowalski and Beth Hahn (both USFS) continued to be champions for Region I mollusk inventories upon Fred's retirement. Henning Stabins (Plum Creek Timber Company) and the Amphibian Inventory Project provided us with additional records of SOC mollusk species helping fill significant gaps in distributions. Bill Bosworth, Zoologist with the Idaho Conservation Data Center, provided the Montana Natural Heritage Program (MTNHP) with location data on SOC species tracked in the
Idaho portions of the Northern Region; the Idaho records were especially critical for the production of new distribution maps in 2005, and fleshing out distributions of rare land mollusk species occurring on both sides of the Idaho-Montana border. Bill Leonard (Olympia, WA) and Tim Pearce (Carnegie Museum of Natural History) verified our tentative SOC and SOI slug identifications in 2005. Ryan Killackey conducted some of the surveys in 2006 and added many important new records. Vick and Rick Applegate, Paul Olson, and Steve Schlang invited Hendricks to participate in their week-long traverse of the Scapegoat Wilderness in 2007 and helped him in the hunt for alpine snails on the Scapegoat Plateau. We thank them all. 


\section{Table of Contents}

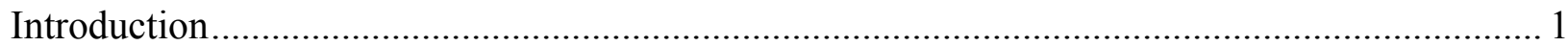

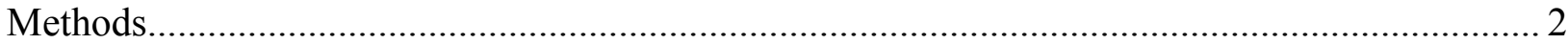

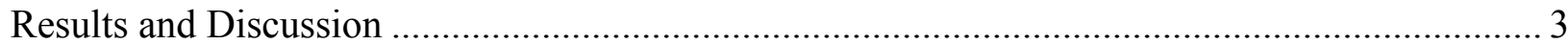

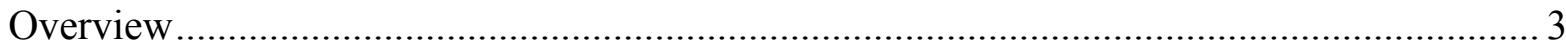

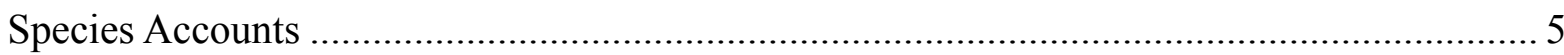

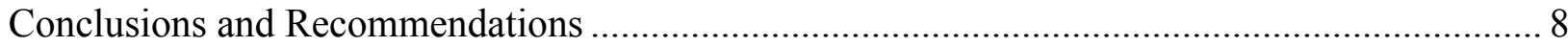

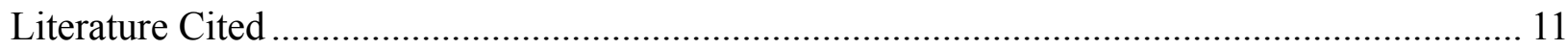

Appendix A: Global and State Rank Definitions

Appendix B: Data Forms

Appendix C: USFS Northern Region Survey Sites in 2007 for Land Molluscks

Appendix D: Observations of the Scapegoat mountainsnails (Oreohelix)

Appendix E: Predicted Distribution Models for Northern Region Land Mollusks

\section{List of Figures}

Figure 1. Map of northwestern Montana showing locations of land mollusks

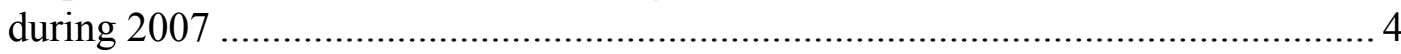

Figure 2. Prioritization of areas lacking land mollusk surveys on U.S. Forest Service Northern Region lands as determined by predicted distribution models ................... 9

Figure 3. Distribution of elevations on U.S. Forest Service Northern Region lands in Montana across a $90 \mathrm{~m}$ pixel digital elevation model 10

Figure D1. Alpine Mountainsnail (Oreohelix alpina) on 24 July 2007 in situ under limestone block at about $8000 \mathrm{ft}$ on the Scapegoat Plateau ....... Appendix D-1

Figure D2. Alpine Mountainsnail on the underside of a limestone block .............. Appendix D-1

Figure D3. Local habitat typical of sites occupied by the Alpine Mountainsnail on the Scapegoat Plateau. Appendix D-1

Figure D4. Landscape view from $8000 \mathrm{ft}$ of the Scapegoat Plateau where Alpine Mountainsnails were found. Summit of Scapegoat Mountain (9202 ft) in the background Appendix D-1

Figure D5. Carinate Mountainsnail (Oreohelix elrodi) on 24 July 2007 in situ under limestone block at about $7900 \mathrm{ft}$ on the Scapegoat Plateau ....... Appendix D-2

Figure D6. Carinate Mountainsnails Appendix D-2

Figure D7. Local habitat typical of sites occupied by the Carinate Mountainsnail on the Scapegoat Plateau Appendix D-2

Figure D8. Landscape view from $8000 \mathrm{ft}$ of the Scapegoat Plateau where Carinate mountainsnails were found. Occupied sites were along the margins of the relatively flat basin in the center-right of the photograph Appendix D-2

Figure D9. Relationship of shell height to shell diameter for the Alpine Mountainsnail (Oreohelix alpina) Appendix D-3

Figure D10. Relationship of shell height to shell diameter for the Carinate Mountainsnail (Oreohelix elrodi). Appendix D-4 


\section{List OF Figures (CON'T)}

Figure E1. Predicted Distribution Model for Smoky Taildropper ........................Appendix E-9

Figure E2. Omission versus Predicted Area.....................................................Appendix E-10

Figure E3. Receiver Operating Characteristic (ROC) Plot ................................Appendix E-11

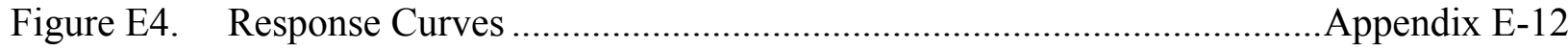

Figure E5. Jackknife Chart........................................................................Appendix E-14

\section{LisT OF TABLES}

Table 1. Number of survey sites where Species of Concern land mollusks were detected on Northern Region Forests in Montana during the

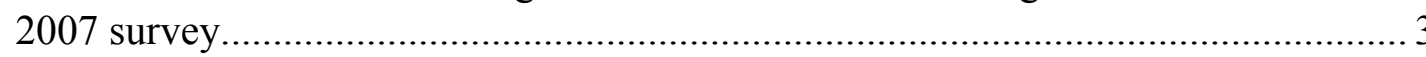

Table D1. Shell morphology for Oreohelix alpina from three Montana mountain ranges.

Appendix D-2

Table D2. Shell morphology for Oreohelix elrodi from three Montana mountain ranges Appendix D-3

Table E1. Overview of Land Mollusk Observations Used in Modeling Effort and Model Comments. Appendix E-3 



\section{INTRODUCTION}

The Northern Region encompasses the ranges of a large number of land mollusk species endemic to the Northern Rocky Mountains, and several additional species restricted to the Pacific Northwest with disjunct populations in northern Idaho and northwestern Montana (Frest and Johannes 1995, 1997, 2001; Hendricks 2003; Hendricks et al. 2006). The US Forest Service is required under the National Forest Management Act (1976) and Code of Federal Regulations (CFR 1985) to maintain a diversity of plant and animal species. Inventory is a first step in the evaluation of landscapes and their likelihood of supporting populations of animal species of conservation concern. Pursuant with this legislation and associated regulations, the Northern Region initiated surveys in 2005 for a suite of land mollusks listed as Species of Concern in Montana and Idaho (Hendricks et al. 2006).

Objectives of the 2005 inventory included filling species distribution gaps, testing survey methodology, and collecting geospatial and habitat data for the development of predictive habitat and distribution models that can aid future survey efforts. The survey was continued in 2006 and 2007 with the same objectives, and with the Montana Natural Heritage Program restricting its field effort to the nine National Forests within Montana (Hendricks et al. 2007). 


\section{Methods}

Prior to conducting field surveys in 2005, we searched the published and gray literature to compile a list of high-priority "target" species (globally and state rare species in Montana, and globally rare species in Idaho). Primary sources we used for this compilation included Pilsbry (1939, 1948), Frest and Johannes (1995, 1997, 2001), and Hendricks (2003). This resulted in a list of 41 species and subspecies (31 snails, 10 slugs) we considered to be of conservation concern (Table 1 in Hendricks et al. 2006); 12 of these taxa are ranked less than G3 (see Appendix A for ranks definitions). We then generated a list of general habitat associations for the high-priority species (Table 2 in Hendricks et al. 2006), to help us prioritize habitats for our surveys during 2005 2007. Extremely limited information for mollusks east of the Continental Divide in Montana made this process more problematic for the high-priority species that occur or might occur in that region. Of the 41 species and subspecies identified as of conservation interest on or near the USFS Northern Region, 19 (11 snails, 8 slugs) occur in Montana and were the primary focus of survey efforts in 2006-2007.

In 2007, we conducted field surveys for land mollusks in late July during a high-elevation mountain traverse, and in September to early October, when the weather was most suitable at lower elevations (cool and moist) for finding active snails and slugs. In 2007, unlike prior years, we concentrated our surveys on filling geographic data gaps, especially targeting areas along or near political boundaries. We also restricted our attention to areas near or west of the Continental Divide, because this is the region with the largest number of Species of Concern (SOC). Thus survey effort in 2007 was non-random and concentrated in three areas within the Northern Region: 1) the northern portion of the Kootenai National Forest near the British Columbia border, 2) portions of the Lolo National Forest near the Idaho border, and 3) a backcountry section of the Lewis and Clark National Forest in the Scapegoat Wilderness.

We selected sites for surveys based primarily on the presence of perennial water, moist mature conifer forest, aspen, and/or limestone talus or other rock outcrops. At each site, we conducted timed surveys while searching under leaf litter, dead wood and bark, rocks imbedded in the ground, or digging into talus. Usually within a survey site we searched several locations with habitat features (such as bryophyte mats, dead wood and imbedded rocks, or talus slopes) considered by experts to be favored by snails and slugs, often concentrating searches in riparian zones.

We recorded a variety of habitat and site information at each survey location on standardized data forms (Appendix B), and digital photographs were taken at all sites. Survey data from 2007 have been entered into the Montana Natural Heritage Program Point Observation Database (POD); copies of the Idaho POD data collected in 2005 were sent to the Idaho Conservation Data Center (CDC) in Boise. We collected voucher specimens of all SOC taxa we discovered, as well as representatives of many other non-SOC taxa; vouchers were preserved in $95 \% \mathrm{ETOH}$ in order to permit future genetic analyses. We sent SOC slug vouchers collected in 2005 to taxonomic experts. Their identifications were verified, and we used this knowledge to make species determinations for the 2006-2007 material.

Point observation data was used to generate predictive distribution models and map outputs. The modeling effort and interpretation of an example output are included in Appendix E and outputs for individual species are available on the Montana Field Guide website: http://fieldguide. mt.gov 


\section{Results AND Discussion}

\section{Overview}

We conducted a total of 34 site surveys in 2007 (Appendix C). These were distributed on the Montana Forests as follows: Kootenai (16), Lewis \& Clark (8), and Lolo (10). Land mollusks were found at all sites surveyed, represented by one to ten species per site ( 30 species total). Of these, only three species (all non-SOC/SOI) were found on all three Forests: Forest Disc (Discus whitneyi), Brown Hive (Euconulus fulvus), and Spruce Snail (Microphysula ingersollii). We documented a total of 23 species on the Kootenai National Forest, seven species on the Lewis and Clark National Forest, and 18 species on the Lolo National Forest. SOC and/or SOI taxa were documented at 19 (55.9\%) of the sites, mostly west of the Continental Divide. The areas surveyed addressed some of the gaps identified in our report of the 2006 inventory (Hendricks et al. 2007).

We documented 38 locations for nine USFS Region 1 SOC taxa and two SOI taxa during our 2007 surveys (Table 1): Alpine Mountainsnail Oreohelix alpina (1 site), Carinate Mountainsnail Oreohelix elrodi (1 site), Humped Coin Polygyrella polygyrella (1 site), Fir Pinwheel Radiodiscus abietum (6 sites), Pale Jumping-slug Hemphillia camelus (4 sites), Marbled Jumping-slug Hemphillia danielsi (1 site), Magnum Mantleslug Magnipelta mycophaga (4 sites), Pygmy Slug Kootenaia burkei (9 sites), Smoky Taildropper Prophysaon humile (6 sites), Lyre Mantleslug Udosarx lyrata (1 site), and Sheathed Slug Zacoleus idahoensis (4 sites). Most locations are from west of the Continental Divide in mesic forest habitats (e.g., western redcedar, western hemlock, mesic Douglas-fir, grand fir), but locations for the two mountainsnails (Oreohelix) were exposed rocky limestone terrain above treeline on the Scapegoat Plateau just east of the Continental Divide (Appendix D).

In 2007, we collected additional location data for two SOC slug species discovered on the Kootenai National Forest in 2005 and new at that time to the Montana mollusk fauna. Pygmy Slug has now been documented at 20 sites; one of the new Pygmy Slug sites is on the Lolo National Forest, making four total sites on the Lolo and 16 on the Kootenai. Pale Jumping-slug has now been documented at seven sites, all on the Kootenai National Forest. We documented an additional location for the Marbled Jumping-slug on the Lolo National Forest in Mineral County. The St. Regis

Table 1. Number of survey sites where Species of Concern land mollusks were detected on Northern Region Forests in Montana during the 2007 survey ( $n=34$ sites).

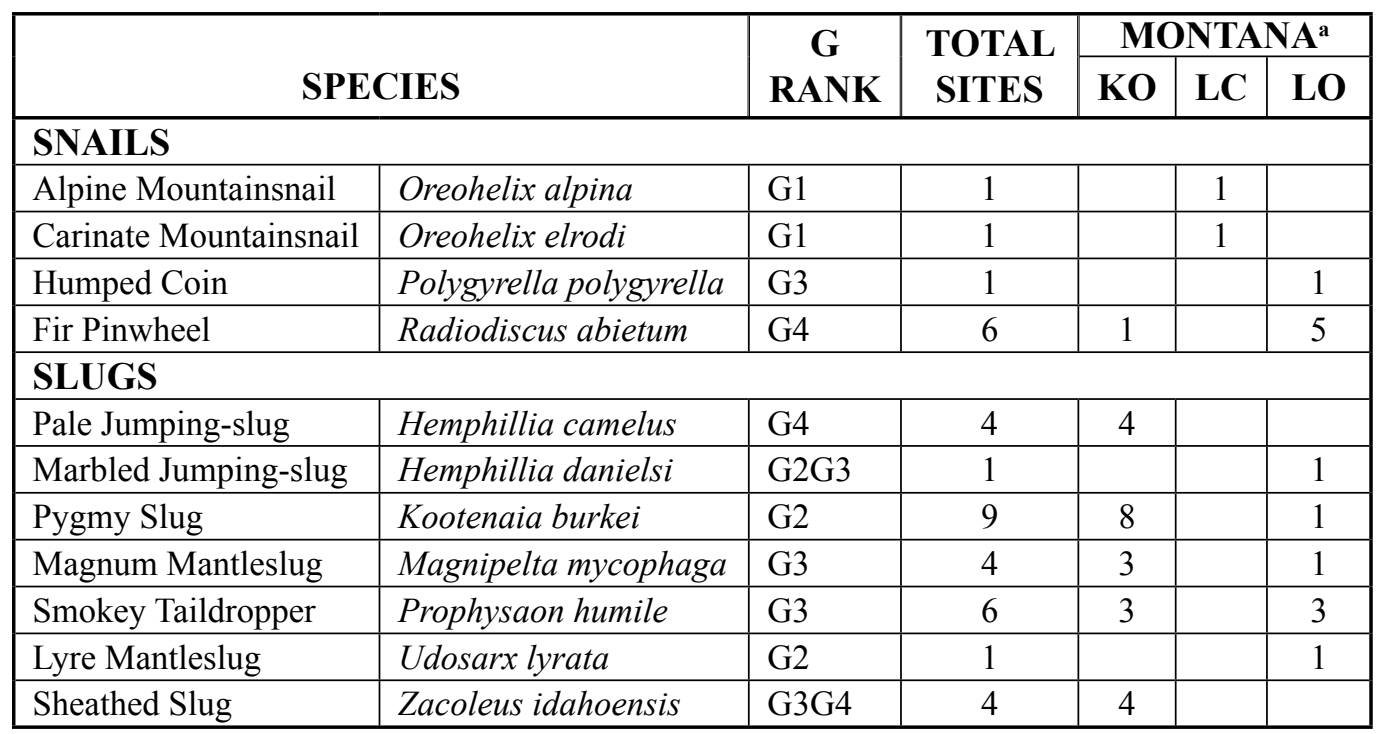

${ }^{a}$ Montana Forests codes: Kootenai (KO), Lewis \& Clark (LC), Lolo (LO). 


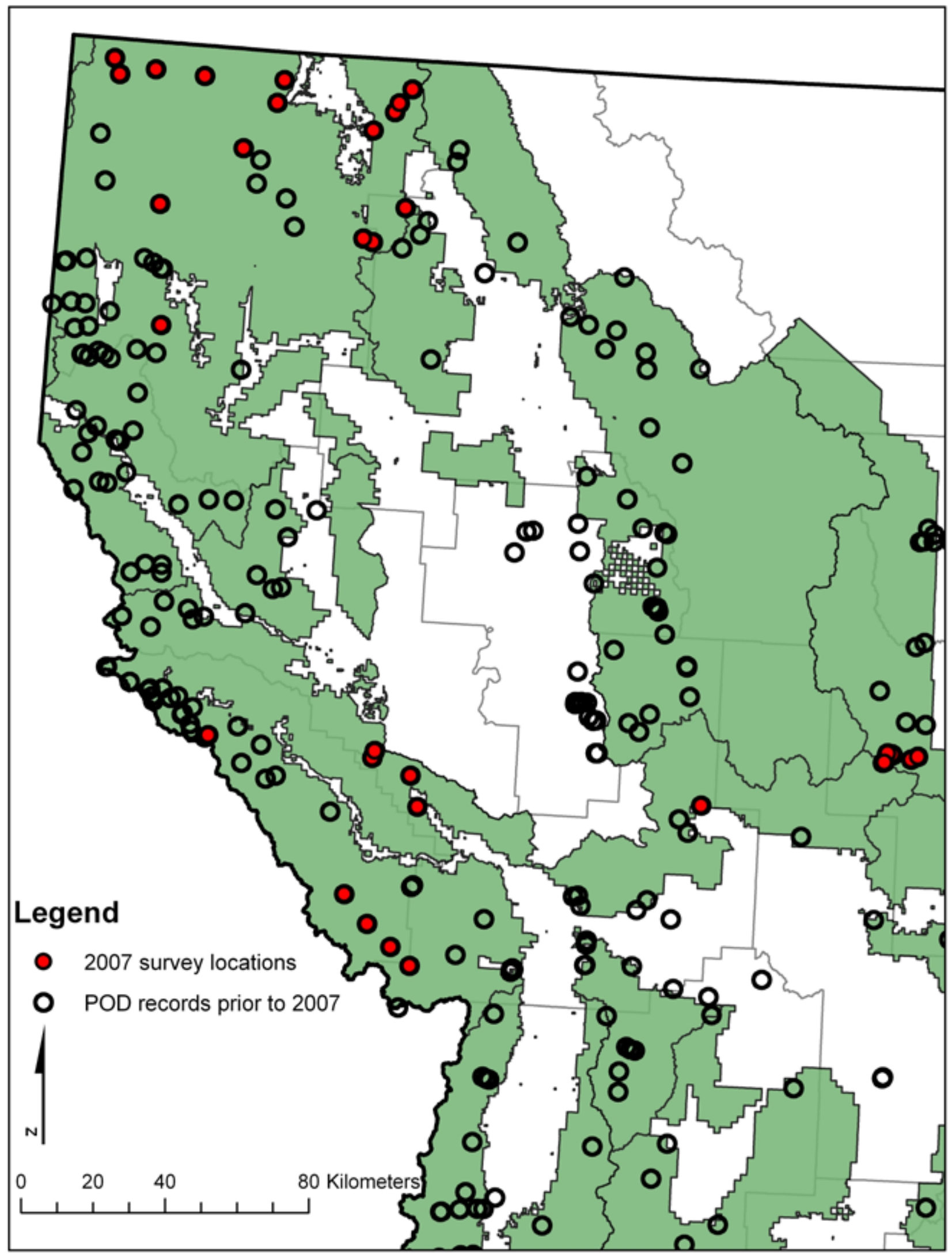

Figure 1. Map of northwestern Montana showing locations of land mollusks during 2007. 
River appears to be the barrier separating this from the congeneric Pale Jumping-slug, but more field (and lab) work would help determine the ranges of these two species in Montana.

The 2007 survey added six Montana locations to the 31 from 2006 for the Smoky Taildropper, thereby bringing the total locations to about 41 for a G3 slug which was documented in Montana only once prior to 2004. We also documented four new locations of Magnum Mantleslug, bringing the total Montana locations to about 25 (Hendricks et al. 2006). To date, the slug with the fewest reported localities in Montana (other than the recently-documented Pale Jumping-slug) is the Lyre Mantleslug, known from just seven sites, even though it was first documented in the state in 1965 (Russell and Webb 1980); four of the sites were discovered during 2006-2007.

As a result of the 2005 surveys, the Global Rank of Humped Coin changed from G2G3 to G3 (see Appendix A for definitions), the Fir Pinwheel changed from G3 to G4, Pale Jumping-slug changed from G3G4 to G4, the Pygmy Slug changed from G1G2 to G2, and Smoky Taildropper changed from G2 to G3. Updated Global and State Ranks are included in Appendix E, Table 1. These updates are a result of the 2005-2007 surveys, the detection probability and site occupancy surveys conducted in 2006 and 2007, and the predicted distribution models produced in 2007. In summary, the 2005-2007 Northern Region surveys have made a significant contribution to our understanding of the current status of several land mollusk species of conservation interest in Montana.

Finally, we recorded 19 additional land mollusk species (including exotics) as we encountered them during our 2007 surveys. These species are not currently recognized as SOC or SOI, nor are they likely to merit such status, and will not be discussed further in this report. Distribution maps showing locations where we found these taxa can be viewed at the Montana Natural Heritage Program Tracker website http://nhp.nris.state. mt.us/Tracker. Available for viewing are all of our survey records for all species, including two of the Chrome Ambersnail (Catinella rehderi) from Carbon and Fergus counties, Montana. Species of Catinella are impossible to identify to species based on shells alone (T. Pearce personal communication), so our identification of shells from these sites remains tentative, and influenced by one prior Montana record from Meagher County (Pilsbry 1948).

\section{Species Accounts}

Alpine Mountainsnail (Oreohelix alpina): We found this species scattered among several locations at one site (the Scapegoat Plateau NW of Scapegoat Mountain) between 7790-8075 ft elevation in Lewis and Clark County, on the Rocky Mountain RD of the Lewis \& Clark National Forest (Appendix C). This is the easternmost documented location for the species so far, an extension of about 38 miles $(61 \mathrm{~km})$ ESE of the Rumble Lake site in the Swan Range (Fairbanks 2002). The Alpine Mountainsnail is a Montana endemic, known only from the Mission and Swan ranges prior to 2007 (Elrod 1903b; Hendricks 1998; Fairbanks 2002), and tied to alpine and high-elevation subalpine limestone talus. Approximately 60 live individuals and 100 shells were found. No locations of sympatry with the Carinate Mountainsnail were found on the Scapegoat Plateau. Additional details regarding this species are presented in Appendix D.

Carinate Mountainsnail (Oreohelix elrodi): We found this species scattered among several locations at one site (the Scapegoat Plateau NW of Scapegoat Mountain) between 7850-7960 ft elevation in Lewis and Clark County, on the Rocky Mountain RD of the Lewis \& Clark National Forest (Appendix C). This is the easternmost documented location for the species so far, an extension of about 44 miles $(71 \mathrm{~km})$ ESE of the Dog Creek site discovered in the Swan Range in 2005 by Henning Stabins. The Carinate Mountainsnail is a Montana endemic, known only from the Mission and Swan ranges prior to 2007 (Elrod 1903a; Fairbanks 1984; Hendricks 1998, 2003). In these ranges it is found primarily in argillite talus with or without overhead canopy, and well-below treeline. On the Scapegoat Plateau it was found under alpine limestone talus and blocks with no overhead canopy. Approximately 100 live individuals and 400 shells were found. No locations of sympatry with the 
Alpine Mountainsnail were found on the Scapegoat Plateau. Additional details regarding this species are presented in Appendix D.

Humped Coin (Polygyrella polygyrella): We found this species at one site at $4100 \mathrm{ft}$ elevation in Mineral County, on the Superior RD of the Lolo National Forest (Appendix C). The Humped Coin, first described from Montana and Idaho by Bland and Cooper (1861) and Cooper (1868), is also present in adjacent Washington and Oregon (Frest and Johannes 1995, 2001). All known Montana sites are clustered in Sanders and Mineral counties (Hendricks 2003, 2005; Hendricks et al. 2006, 2007). Canopy at the 2007 site included western redcedar, western hemlock, grand fir, and Engelmann spruce. One live animal was found under $\mathrm{a}>20 \mathrm{~cm}$ rock at this site.

Fir Pinwheel (Radiodiscus abietum): We found this species at six sites between 3140-4960 ft elevation, in Lincoln, Mineral, Missoula, and Sanders counties, on the Libby RD of the Kootenai National Forest, and the Missoula, Ninemile, and Plains RDs of the Lolo National Forest (Appendix C). The Fir Pinwheel is restricted to northern Idaho, western Montana, and adjacent parts of Oregon and Washington (Brunson and Russell 1967; Frest and Johannes 1995, 2001; Hendricks 2003, 2005; Hendricks et al. 2006, 2007). Canopy at the 2007 sites included western redcedar, grand fir, Douglas-fir, alder, black cottonwood, and western larch. Single live individuals were present at each site, mostly under downed wood, but also rocks and leaf litter.

Pale Jumping-slug (Hemphillia camelus): We found this species at four sites between 2980-4800 $\mathrm{ft}$ elevation, in Lincoln County, on the Rexford and Three Rivers RDs of the Kootenai National Forest (Appendix C). This species was first documented in Montana during the 2005 survey (Frest and Johannes 1995; Hendricks 2003; Hendricks et al. 2006, 2007). The Pale Jumping-slug appears to be restricted to northern Idaho, and adjacent parts of Washington, British Columbia, Alberta, and now Montana (Frest and Johannes 1995, 2001; Forsyth 2004). Frest and Johannes $(1997,2001)$ suggested that individuals from the Lower Salmon River drainage in Idaho might represent a taxon distinct from that to the north, but this possibility has not been resolved. Canopy at the 2007 sites included western redcedar, subalpine fir, Engelmann spruce, western hemlock, western larch, lodgepole pine, ponderosa pine, and alder. Between three and eight individuals (20 total) were found at each site under downed wood, leaf litter, and rock.

Marbled Jumping-slug (Hemphillia danielsi): We found this species at one site, at $4100 \mathrm{ft}$ elevation in Mineral County, on the Superior RD of the Lolo National Forest (Appendix C). This species was first documented in Montana in 1912 (Vanatta 1914; Frest and Johannes 1995; Hendricks 2003). Until recently, the global range was exclusively the Bitterroot Mountains. The Marbled Jumpingslug appears to be restricted to extreme western Montana south of the St. Regis River, near the state line with Idaho (Frest and Johannes 1995, 2001; Hendricks et al. 2006, 2007), although there is an older Hemphillia record near Flathead Lake that has been tentatively assigned to this species; the species also occurs in adjacent Idaho, but the distribution as yet is not well-defined. Canopy at the 2007 site included western redcedar, grand fir, Engelmann spruce, and western hemlock. A single individual was found under downed rotten wood.

Pygmy Slug (Kootenaia burkei): We found this species at nine sites between 2680-4800 ft elevation in Lincoln and Mineral counties, on the Libby, Rexford, and Three Rivers RDs of the Kootenai National Forest and the Superior $\mathrm{RD}$ of the Lolo National Forest (Appendix C). Only recently was this species first discovered and described, from five sites in northern Idaho (Leonard et al. 2003). It was documented in Montana for the first time at four sites during the 2005 survey (Hendricks et al. 2006), and at seven more sites in 2006 (Hendricks et al. 2007). Canopy at the 2007 sites included western redcedar, grand fir, Engelmann spruce, western hemlock, subalpine fir, lodgepole pine, ponderosa pine, alder, and western larch. Up to 26 individuals (41 total) were found on and under downed wood, under rock fragments, and among leaf litter. 
Magnum Mantleslug (Magnipelta mycophaga):

We found this species at four sites between 3140$4500 \mathrm{ft}$ elevation in Lincoln and Mineral counties, on the Fortine and Libby RDs of the Kootenai National Forest and the Superior RD of the Lolo National Forest (Appendix C). Prior to the 2006 survey, this slug was known from $<20$ sites in Montana (Hendricks 2003; Hendricks et al. 2006, 2007 ) and remains documented at $<30$ sites following the 2007 survey. Canopy at the 2007 sites included western redcedar, western hemlock, Engelmann spruce, grand fir, Douglas-fir, alder, and black cottonwood. Single animals were found at each site under downed rotten wood or rock.

Smoky Taildropper (Prophysaon humile): We found this species at six sites between 3140-4640 $\mathrm{ft}$ elevation in Lincoln, Missoula, and Sanders counties, on the Libby and Three Rivers RDs of the Kootenai National Forest, and the Ninemile and Plains RDs of the Lolo National Forest (Appendix C). This species is known only from northern Idaho and adjacent northwestern Montana (Pilsbry 1948; Frest and Johannes 1995, 2001; Hendricks 2005; Hendricks et al. 2006, 2007). Prior to 2004 this slug was known in Montana from a single site. Following the 2007 surveys, it has now been documented at about 41 sites. Canopy at the 2007 sites included western redcedar, grand fir, Douglasfir, Engelmann spruce, western larch, subalpine fir, lodgepole pine, alder, and black cottonwood. Up to three individuals (nine total) were found under downed rotten wood.
Lyre Mantleslug (Udosarx lyrata): We found this species at one site at $4640 \mathrm{ft}$ elevation in Missoula County, on the Ninemile RD of the Lolo National Forest (Appendix C). This species is restricted to northern Idaho and adjacent parts of western Montana (Webb 1959; Russell and Webb 1980; Frest and Johannes 1995, 2001; Hendricks 2003; Hendricks et al. 2006, 2007). Two subspecies are described but we are unable to distinguish these, and assign our records only to the species level. Although known from Montana since 1965, there remain only seven reported locations in the state, three of which were found in 2006. Globally, there are fewer than 15 records (Hendricks et al. 2006, 2007). Canopy at the 2007 site included Engelmann spruce, Douglas-fir, and alder. Only a single animal was found, under downed rotten wood.

Sheathed Slug (Zacoleus idahoensis): We found this species at four sites between 2680-3630 ft elevation in Lincoln County, on the Libby, Rexford, and Three Rivers RDs of the Kootenai National Forest (Appendix C). This species is restricted to northern Idaho and adjacent northwestern Montana (Pilsbry 1948; Frest and Johannes 1995, 2001; Hendricks 2003; Hendricks et al. 2006, 2007). The total number of documented Montana localities is 33 following the 2007 surveys. Canopy at the 2007 sites included western redcedar, Engelmann spruce, lodgepole pine, ponderosa pine, western larch, and alder. One to two individuals were found at each site (six total), under wet downed rotten wood, rock fragments, or leaf litter. 


\section{Conclusions and Recommendations}

The number of new locations we discovered (176 total) for 16 of 19 species of land mollusks of conservation concern during our 2005-2007 surveys in the Montana portion of the USFS Northern Region area underscores our conclusion that current knowledge of the distribution, ecology, and status of this suite of species remains far from thorough. Although we have accumulated many new records for Species of Concern on Forest Service lands during the surveys, many taxa remain documented from $<25$ locations. Of course, some of these may be so rare that they will never be found at more than a handful of sites, but we predict new locations eventually will be documented for most.

We think, however, an additional year of nonrandom surveys, similar to those of 2005-2007, would help fill distribution gaps and gather additional habitat information. We also suggest a minimum of one additional year of random site surveys are needed to determine site occupancy rates as a measure of status in various habitats. It is important these be conducted under environmental conditions when land mollusks are most likely to be active.

Developing predictive habitat or ecological niche models may also prove useful for guiding surveys of some species groups, especially those associated with the moist forest types mentioned earlier. To increase the utility of predictive habitat models, it is important that more-detailed habitat data are recorded when and where SOC and SOI species are found. Recent examples of the use of predictive models for conservation management of rare land mollusks in the Pacific Northwest and Black Hills are Dunk et al. (2004), Gaines et al. (2005), and Weaver et al. (2006).

Appendix E provides an overview of inputs, an example output, and a guide to interpretation of outputs for the predicted distribution models. Model output for individual species can be viewed under individual species accounts on the on-line Animal Field Guide website at http://fieldguide. mt.gov. Overall, the predicted distribution model output indicates that the known ranges of a number of species may be extended by focusing future survey effort in the vicinity of Glacier National Park, the Seeley/Swan area, the South Fork of the Flathead River drainage, the Mission Mountains and the Bitterroot Mountains in Mineral County (Figure 2). Major gaps in survey effort on U.S. Forest Service lands still exist in a number of areas, but model output indicates that the greatest number of gaps in known species ranges (especially Species of Concern) may be filled in with additional surveys focused on portions of northwestern Montana, the Bitterroot Mountains in Mineral and Ravalli Counties, Beaverhead, Madison, and Silver Bow Counties, and portions of the island mountain ranges in eastern Montana (Figure 2). In addition to these gaps, a summary of elevations on U.S. Forest Service lands in Montana and elevations of mollusk survey locations in 20052007 indicates that high elevation sites have been under-sampled (Figure 3). We intend to target these areas during the 2008 field season.

In addition to targeting these areas for survey, we continue to recommend the following actions as expressed in previous reports (Hendricks et al. 2006, 2007): (1) Survey and modeling efforts should continue to be coordinated with the Idaho CDC and MTNHP; this coordination is especially desired to determine more fully the status of the many SOC and SOI species shared in the two states; (2) There remains a need for genetic studies to inform current taxonomy of some species. We think some taxa currently considered conspecific with coastal populations (e.g., Robust Lancetooth, Reticulate Taildropper, Blue-gray Taildropper, and Papillose Taildropper) may prove to be distinct sister species (see discussions in Leonard et al. 2003, Ovaska et al. 2004), similar to the results of recent genetic studies of some Pacific Northwest amphibian genera (e.g., Ascaphus, Dicamptodon, Plethodon). Similarly, Oreohelix species across the region that are similar in morphology may represent one species or numerous cryptic species. A genetic study of the phylogeography of these species is needed in order to prevent loss of potentially unique species and/or populations. 
Finally, high elevation taxa like the Alpine Mountainsnail and Carinate Mountainsnail would benefit from genetic analyses to determine if their isolated populations are genetically identical, or if they are distinct enough to be classified as recently-isolated subspecies or sister species (see Appendix D); (3) Development of a field guide to the land mollusks of Montana would compile largely inaccessible pieces of information to heighten awareness of this overlooked and poorly understood group of animals, and provide biologists and managers some of the basic tools they need to make informed management decisions. (4) Finally, after development of a field guide, we think it would be useful to conduct workshops on land mollusk identification and management.

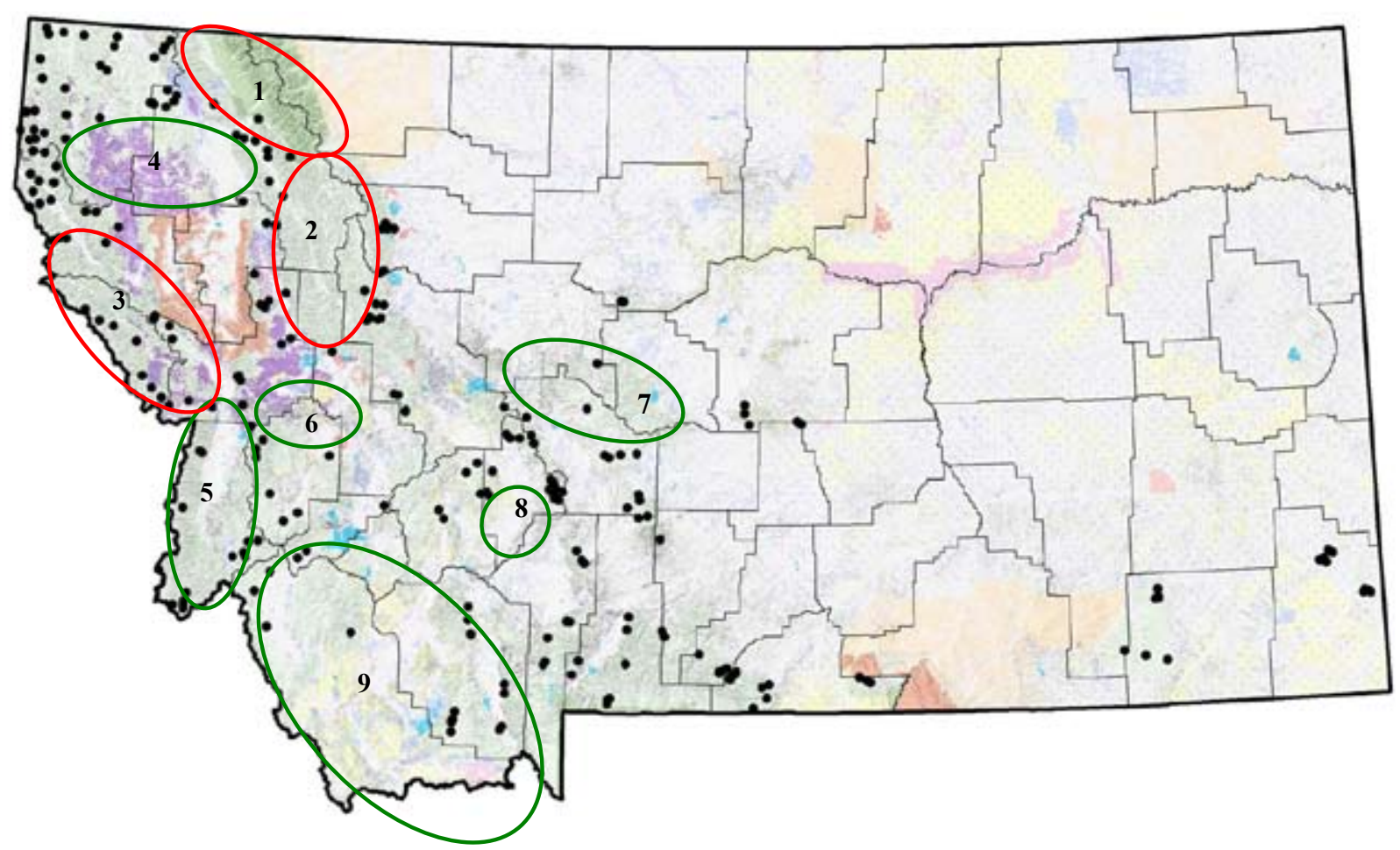

Figure 2. Prioritization (numbers in ovals) of areas lacking land mollusk surveys on U.S. Forest Service Northern Region lands as determined by predicted distribution models. Red ovals encompass areas most likely to result in extensions of known species ranges. Green ovals encompass areas most likely to result in the filling in of major gaps in known species ranges. 


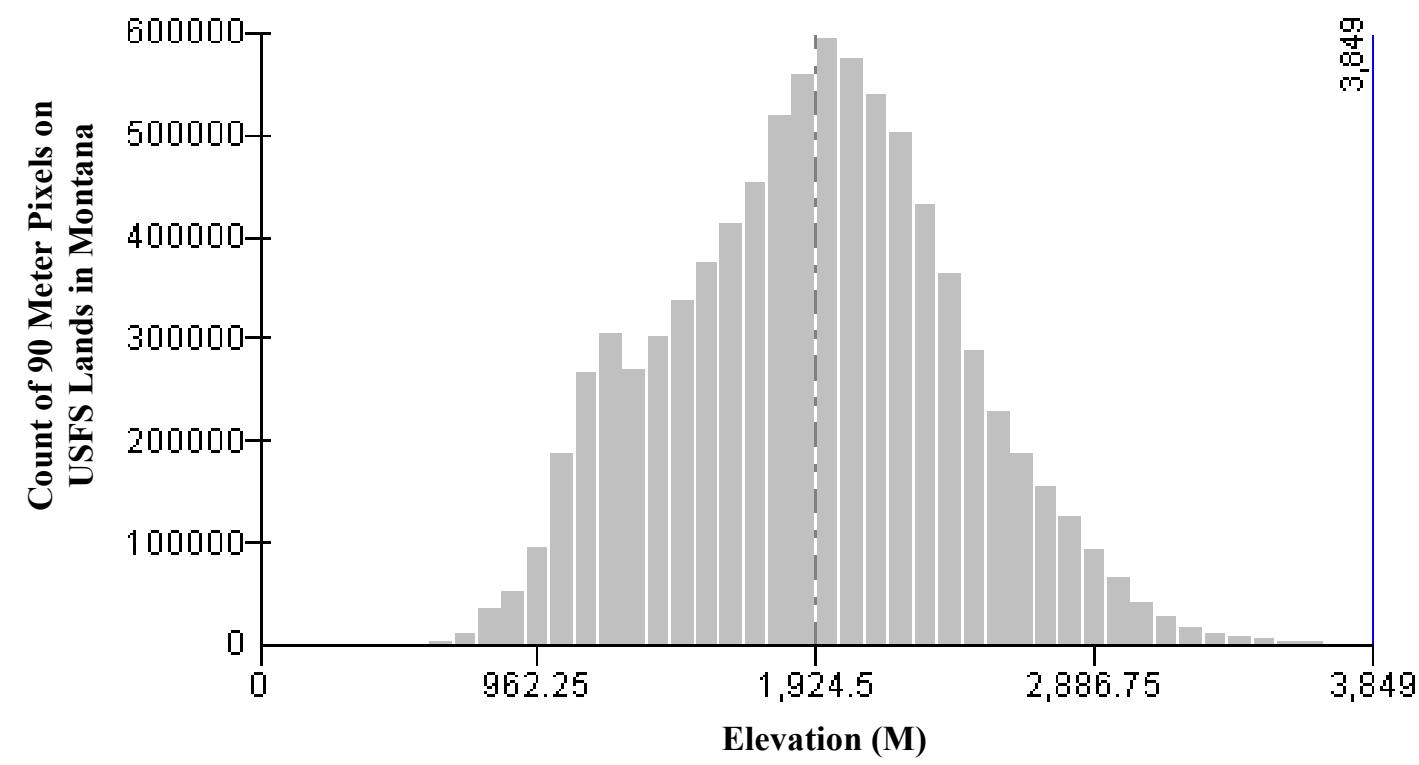

Figure 3. Distribution of elevations on U.S. Forest Service Northern Region lands in Montana across a 90-meter pixel digital elevation model (mean elevation indicated by dashed line). The distribution of land mollusk survey locations is significantly lower than the distribution of available elevations as indicated by the superimposed tall dark line (mean), short dark line (median), and 2 tall light lines (2 standard deviations above and below mean). 


\section{Literature Cited}

Anderson, T. K., and C. Schmidt. 2007.

Population demography of a land snail species of conservation concern in the Black Hills. Intermountain Journal of Sciences 13:13-31.

Anderson, T. K., K. F. Weaver, and R. P. Guralnick. 2007. Variation in adult shell morphology and life-history traits in the land snail Oreohelix cooperi in relation to biotic and abiotic factors. Journal of Molluscan Studies 73:129-137.

Bland, T., and J. G. Cooper. 1861. Notice of land and freshwater shells collected by Dr. J. G. Cooper in the Rocky Mountains, etc., in 1860. Annals of the Lyceum of Natural History of New York 7:362-370.

Brunson, R. B., and R. H. Russell. 1967. Radiodiscus, new to molluscan fauna of Montana. The Nautilus 81:18-22.

CFR (Code of Federal Regulations). 1985. 36 Code of Federal Regulations. Chapter II 219.19:64.

Cooper, J. G. 1868. The shells of Montana. American Naturalist 2:486-487.

Dunk, J. R., W. J. Zielinski, and H. K. Preisler. 2004. Predicting the occurrence of rare mollusks in northern California forests. Ecological Applications 14:713-729.

Elrod, M. J. 1903a. Notes on Pyramidula elrodi Pils. The Nautilus 16:109-112.

Elrod, M. J. 1903b. Montana shells - Pyramidula strigosa. The Nautilus 17:1-6.

Fairbanks, H. L. 1984. A new species of Oreohelix (Gastropoda: Pulmonata: Oreohelicidae) from the Seven Devils Mountains, Idaho. Proceedings of the Biological Society of Washington 97:179-185.
Fairbanks, H. L. 2002. The reproductive anatomy, taxonomic status, and range of Oreohelix alpina (Elrod, 1901) (Gastropoda: Pulmonata: Oreohelicidae). The Nautilus 116:62-65.

Forsyth, R. G. 2004. Land snails of British Columbia. Royal British Columbia Museum, Victoria, BC. 188 pp.

Frest, T. J., and E. J. Johannes. 1995. Interior Columbia Basin mollusk species of special concern. Final Report to Interior Columbia Basin Ecosystem Management Project. Deixis Consultants, Seattle. 274 pp.

Frest, T. J., and E. J. Johannes. 1997. Land snail survey of the lower Salmon River drainage, Idaho. Idaho Bureau of Land Management Technical Bulletin No. 97-18.

Frest, T. J., and E. J. Johannes. 2001. An annotated checklist of Idaho land and freshwater mollusks. Journal of the Idaho Academy of Science 36:1-51.

Gaines, W. L., A. L. Lyons, and A. Sprague. 2005. Predicting the occurrence of a rare mollusk in the dry forests of north-central Washington. Northwest Science 79:99-105.

Hendricks, P. 1998. Rediscovery of Discus brunsoni Berry, 1955 and Oreohelix alpina (Elrod, 1901) in the Mission Mountains, Montana, with comments on Oreohelix elrodi (Pilsbry, 1900). The Nautilus 112:58-62.

Hendricks, P. 2003. Status and conservation management of terrestrial mollusks of Special Concern in Montana. Report to Region 1, U.S. Forest Service. Montana Natural Heritage Program, Helena, MT. 67 pp. + appendices. 
Hendricks, P., Compiler. 2005. Surveys for Animal Species of Concern in northwestern Montana. Report to Montana Department of Fish, Wildlife, and Parks, State Wildlife Grants Program, Helena, Montana. Montana Natural Heritage Program, Helena, MT. 53 pp.

Hendricks, P., B. A. Maxell, and S. Lenard. 2006. Land mollusk surveys on USFS Northern Region lands. A report to the USDA Forest Service, Northern Region. Montana Natural Heritage Program, Helena, Montana. 11 pp. plus appendices.

Hendricks, P., B. A. Maxell, S. Lenard, and C. Currier. 2007. Land Mollusk Surveys on USFS Northern Region Lands: 2006. A report to the USDA Forest Service, Northern Region. Montana Natural Heritage Program, Helena, MT. 11 pp. plus appendices.

Leonard, W. P., L. Chichester, J. Baugh, and T. Wilke. 2003. Kootenaia burkei, a new genus and species of slug from northern Idaho, United States (Gastropoda: Pulmonata: Arionidae). Zootaxa 355:1-16.

Leonard, W. P., L. Chichester, and K. Ovaska. 2003. Prophysaon dubium Cockerell, 1890, the papillose taildropper (Gastropoda: Arionidae): distribution and anatomy. The Nautilus 117:6267.

Ovaska, K., W. P. Leonard, L. Chichester, T. E. Burke, L. Sopuck, and J, Baugh. 2004. Prophysaon coeruleum Cockerell, 1890, bluegray taildropper (Gastropoda: Arionidae): new distributional records and reproductive anatomy. Western North American Naturalist 64:538-543.

Pilsbry, H. A. 1939. Land mollusca of North America (north of Mexico), Volume I Part 1. The Academy of Natural Sciences of Philadelphia Monographs Number 3 (1):1-573.
Pilsbry, H. A. 1948. Land mollusca of North America (north of Mexico), Volume II Part 2. The Academy of Natural Sciences of Philadelphia Monographs Number 3 (2):5211113.

Russell, R. H., and G. R. Webb. 1980. The slug Udosarx lyrata: additional data on distribution, anatomy, and taxonomy. Gastropodia 2:8-10.

Vanatta, E. G. 1914. Montana shells. Proceedings of the Academy of Natural Sciences of Philadelphia 66:367-371.

Weaver, K. F., T. Anderson, and R. Guralnick. 2006. Combining phylogenetic and ecological niche modeling approaches to determine distribution and historical biogeography of Black Hills mountain snails (Oreohelicidae). Diversity and Distributions 12:756-766.

Webb, G. R. 1959. Two new north-western slugs, Udosarx lyrata and Gliabates oregonia. Gastropodia 1(3):22-23, 28. 
Appendix A. Global and State Rank Definitions 



\section{Heritage Program Ranks}

The international network of Natural Heritage Programs employs a standardized ranking system to denote global (range-wide) and state status. Species are assigned numeric ranks ranging from 1 to 5 , reflecting the relative degree to which they are "at-risk". Rank definitions are given below. A number of factors are considered in assigning ranks - the number, size and distribution of known "occurrences" or populations, population trends (if known), habitat sensitivity, and threat. Factors in a species' life history that make it especially vulnerable are also considered (e.g., dependence on a specific pollinator).

Global Rank Definitions (NatureServe 2003)

G1 Critically imperiled because of extreme rarity and/or other factors making it highly vulnerable to extinction

G2 Imperiled because of rarity and/or other factors making it vulnerable to extinction

G3 Vulnerable because of rarity or restricted range and/or other factors, even though it may be abundant at some of its locations

G4 Apparently secure, though it may be quite rare in parts of its range, especially at the periphery

G5 Demonstrably secure, though it may be quite rare in parts of its range, especially at the periphery

T1-5 Infraspecific Taxon (trinomial) - The status of infraspecific taxa (subspecies or varieties) are indicated by a "T-rank" following the species' global rank

\section{State Rank Definitions}

S1

S2

S3

S4

S5

At high risk because of extremely limited and potentially declining numbers, extent and/or habitat, making it highly vulnerable to extirpation in the state At risk because of very limited and potentially declining numbers, extent and/or habitat, making it vulnerable to extirpation in the state

S3 Potentially at risk because of limited and potentially declining numbers, extent and/or habitat, even though it may be abundant in some areas

S4 Uncommon but not rare (although it may be rare in parts of its range), and usually widespread. Apparently not vulnerable in most of its range, but possibly cause for long-term concern Common, widespread, and abundant (although it may be rare in parts of its range). Not vulnerable in most of its range

\section{Combination Ranks}

G\#G\# or S\#S\# Range Rank-A numeric range rank (e.g., G2G3) used to indicate uncertainty about the exact status of a taxon

\section{QUALIFIERS}

NR Not ranked

Questionable taxonomy that may reduce conservation priority-Distinctiveness of this entity as a taxon at the current level is questionable; resolution of this uncertainty may result in change from a species to a subspecies or hybrid, or inclusion of this taxon in another taxon, with the resulting taxon having a lower-priority (numerically higher) conservation status rank 
X

H

U

HYB

?

C

A

Z

P

R

SYN

*

B

$\mathrm{N}$

Presumed Extinct - Species believed to be extinct throughout its range. Not located despite intensive searches of historical sites and other appropriate habitat, and virtually no likelihood that it will be rediscovered

Possibly Extinct - Species known from only historical occurrences, but may never-theless still be extant; further searching needed

Unrankable - Species currently unrankable due to lack of information or due to substantially conflicting information about status or trends

Hybrid - Entity not ranked because it represents an interspecific hybrid and not a species

Inexact Numeric Rank-Denotes inexact numeric rank

Captive or Cultivated Only - Species at present is extant only in captivity or cultiva tion, or as a reintroduced population not yet established

Accidental-Species is accidental or casual in Montana, in other words, infrequent and outside usual range. Includes species (usually birds or butterflies) recorded once or only a few times at a location. A few of these species may have bred on the one or two occasions they were recorded

Zero Occurrences - Species is present but lacking practical conservation concern in Montana because there are no definable occurrences, although the taxon is native and appears regularly in Montana

Potential-Potential that species occurs in Montana but no extant or historic occurrences are accepted

Reported-Species reported in Montana but without a basis for either accepting or rejecting the report, or the report not yet reviewed locally. Some of these are very recent discoveries for which the program has not yet received first-hand information; others are old, obscure reports

Synonym - Species reported as occurring in Montana, but the Montana Natural Heritage Program does not recognize the taxon; therefore the species is not assigned a rank

A rank has been assigned and is under review. Contact the Montana Natural Heritage Program for assigned rank

Breeding-Rank refers to the breeding population of the species in Montana

Nonbreeding - Rank refers to the non-breeding population of the species in Montana

Appendix A - 2 
Appendix B. Data Forms 



\section{Data Form for Terrestrial Mollusk Site Surveys}

Locality Information

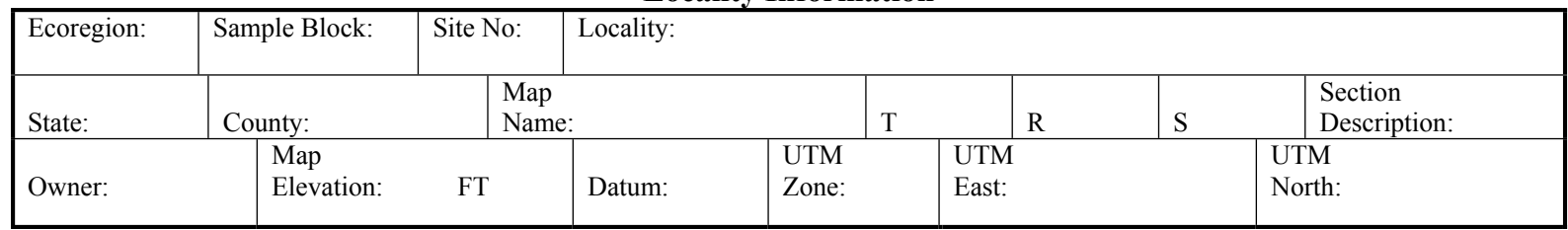

Habitat Information

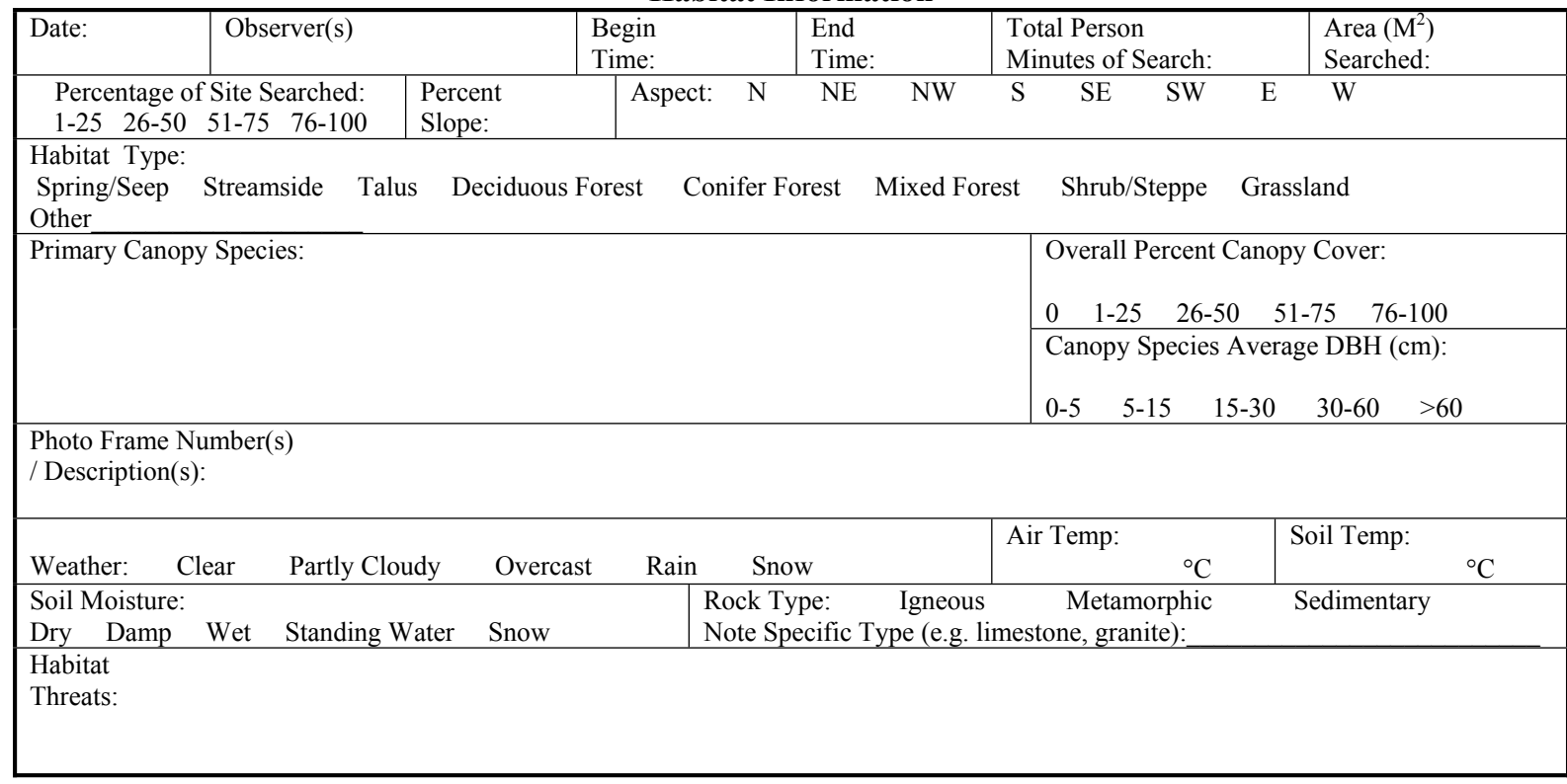

\section{Mollusk Species Information}

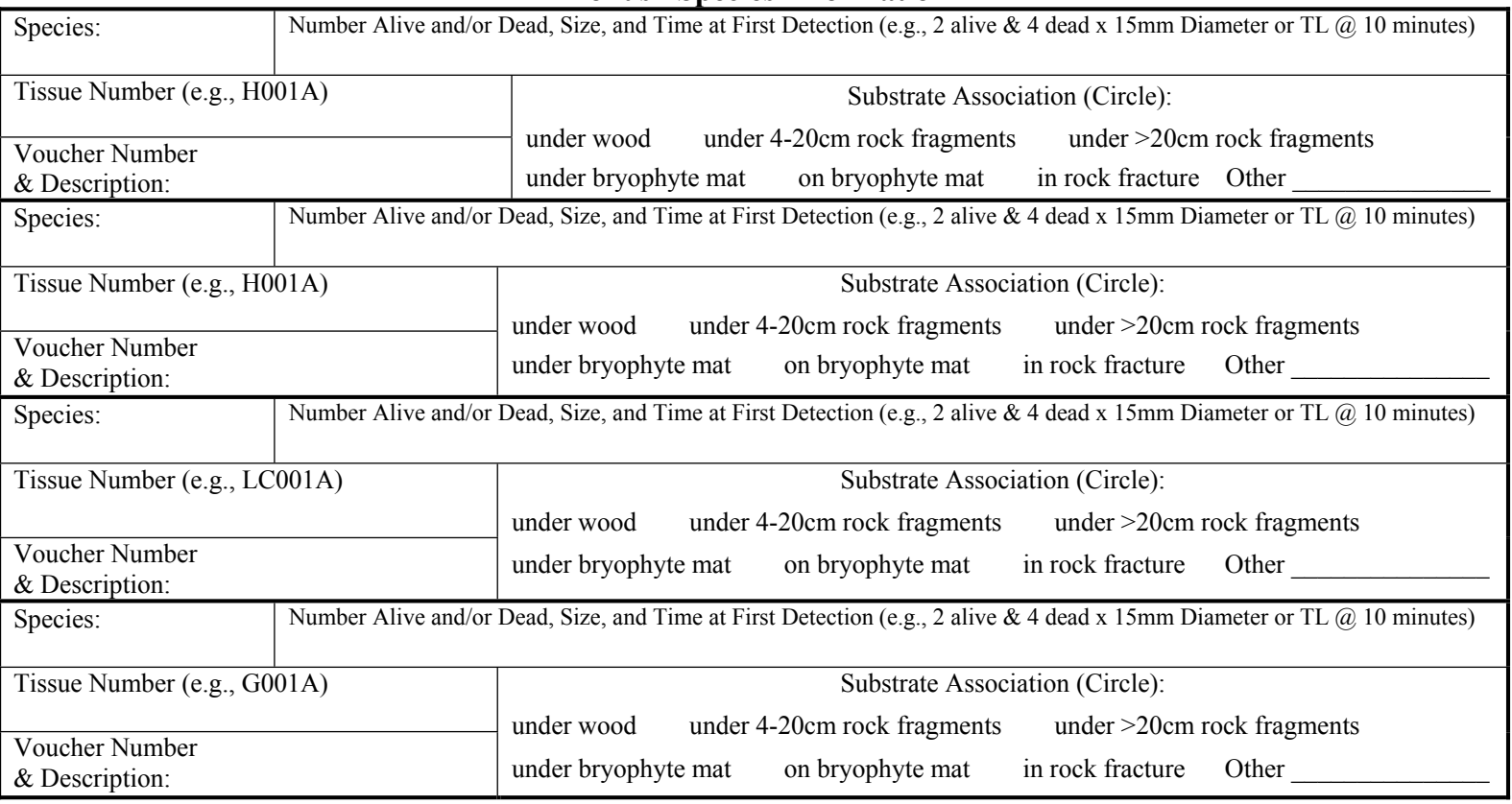


Grid Scale:

Site Map for Terrestrial Mollusk Site Surveys

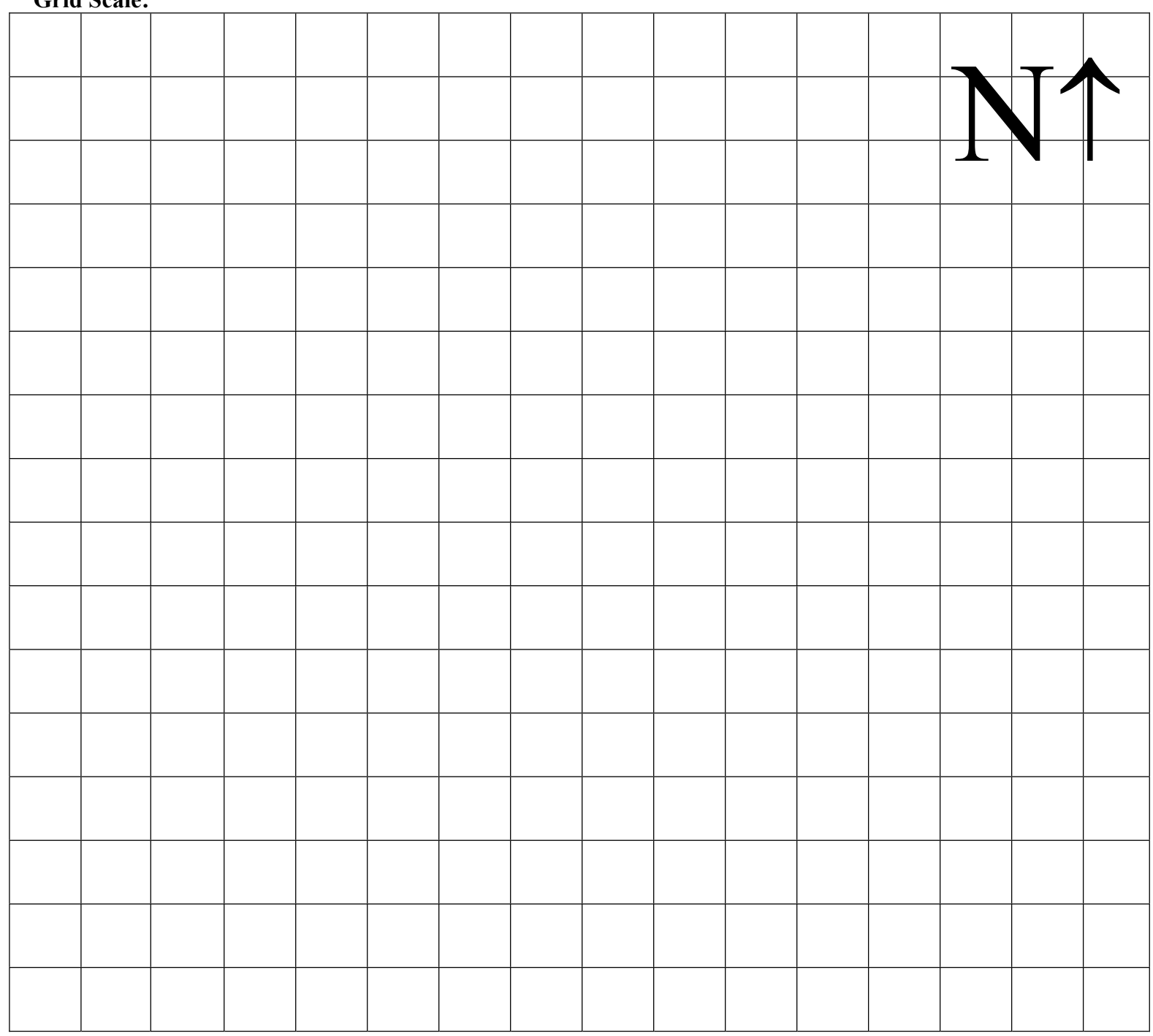

* Draw a rough sketch of the site labeling major features such as streams, talus slopes, habitat cover types, etc. Be sure to indicate where animals were detected and label the following locations on the map: $\mathbf{G}=$ GPS reading, and $\mathbf{P} \rightarrow=$ photo locations and directions of photos.

Other Notes: 
Site ID (ecoregion, sample block, site number)

Date:

Mollusk Species Information Continued

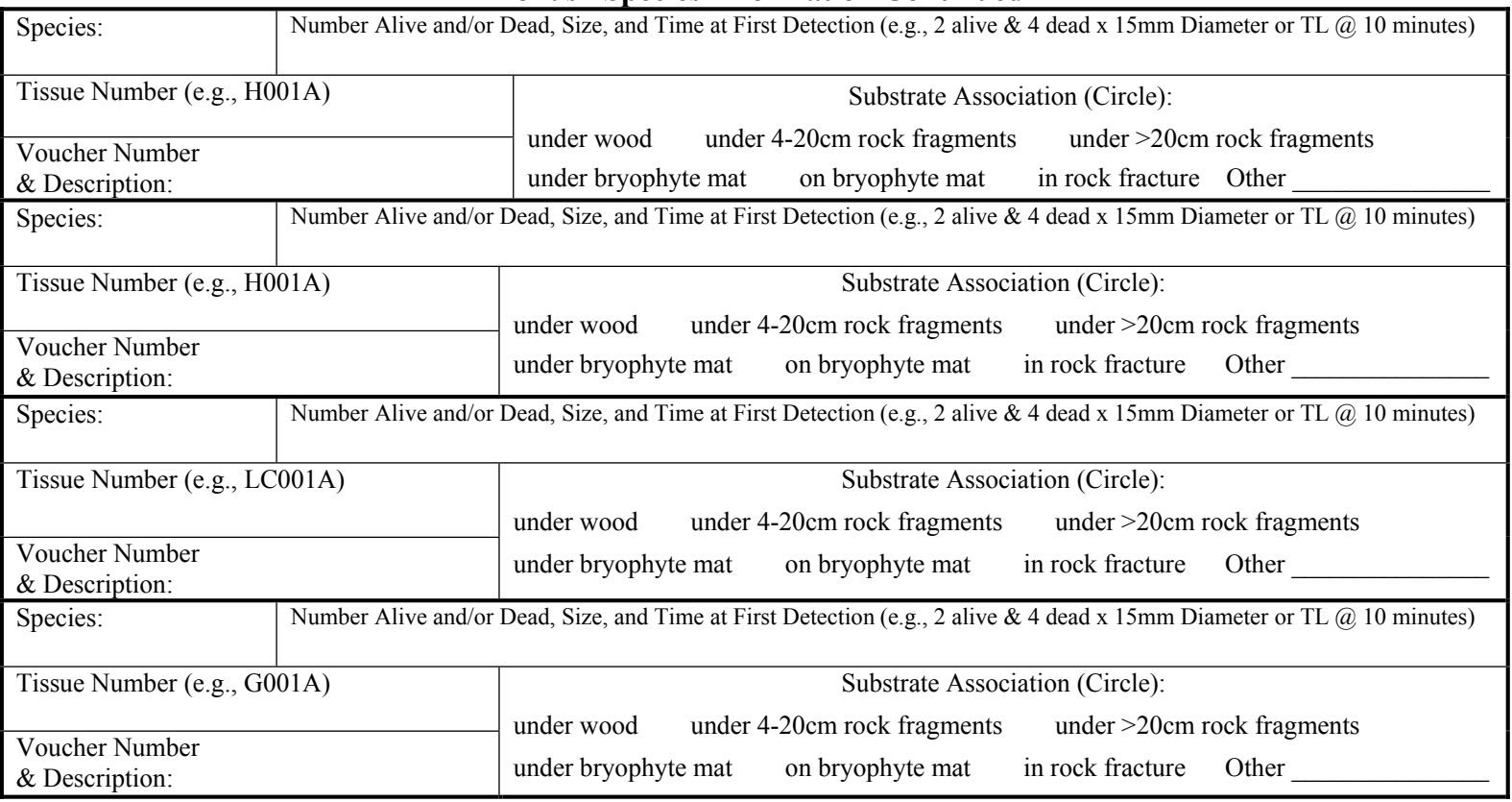

\section{Other Species Information}

\begin{tabular}{|l|l|l|l|}
\hline $\begin{array}{l}\text { Other Species: } \\
\text { (millipedes etc.) }\end{array}$ & $\begin{array}{l}\text { Time at First } \\
\text { Detection: }\end{array}$ & $\begin{array}{l}\text { Voucher } \\
\text { Number: }\end{array}$ & Voucher Description / Comments: \\
\hline $\begin{array}{l}\text { Other Species: } \\
\text { (millipedes etc.) }\end{array}$ & $\begin{array}{l}\text { Time at First } \\
\text { Detection: }\end{array}$ & $\begin{array}{l}\text { Voucher } \\
\text { Number: }\end{array}$ & Voucher Description / Comments: \\
\hline $\begin{array}{l}\text { Other Species: } \\
\text { (millipedes etc.) }\end{array}$ & $\begin{array}{l}\text { Time at First } \\
\text { Detection: }\end{array}$ & $\begin{array}{l}\text { Voucher } \\
\text { Number: }\end{array}$ & Voucher Description / Comments: \\
\hline $\begin{array}{l}\text { Other Species: } \\
\text { (millipedes etc.) }\end{array}$ & $\begin{array}{l}\text { Time at First } \\
\text { Detection: }\end{array}$ & $\begin{array}{l}\text { Voucher } \\
\text { Number: }\end{array}$ & Voucher Description / Comments: \\
\hline $\begin{array}{l}\text { Other Species: } \\
\text { (millipedes etc.) }\end{array}$ & $\begin{array}{l}\text { Time at First } \\
\text { Detection: }\end{array}$ & $\begin{array}{l}\text { Voucher } \\
\text { Number: }\end{array}$ & Voucher Description / Comments: \\
\hline $\begin{array}{l}\text { Other Species: } \\
\text { (millipedes etc.) }\end{array}$ & $\begin{array}{l}\text { Time at First } \\
\text { Detection: }\end{array}$ & $\begin{array}{l}\text { Voucher } \\
\text { Number: }\end{array}$ & Voucher Description / Comments: \\
\hline
\end{tabular}

Other Notes 
Site Information

Ecoregion: One of the 14 ecoregion sections in Montana or 6 in the Idaho Panhandle.

Sample Block: Identify three digit number of the sampling block (range 001-999).

Site No: Identify three digit number of the site being surveyed within each sampling block (range 001-999).

Locality: Describe the specific geographic location of the site so that the type of site is described and the straight-line air distance from one or more permanent features on a 7.5-minute (1:24,000 scale) topographic map records the position of the site (e.g., Large talus slope 1.5 miles north of Engle Peak, N side of FS Road 225).

State: Use the two-letter abbreviation.

County: Use the full county name.

Map Name: List the name of the USGS 7.5-minute (1:24,000 scale) topographic quadrangle map.

T: Record the Township number and whether it is north or south.

R: Record the Range number and whether it is east or west.

S: Record the Section number

Section Description: Describe location of the site at the $1 / 4$ of $1 / 4$ section level (e.g., SENE indicates SE corner of NE corner).

Owner: Use abbreviation of the government agency responsible for managing the land you surveyed. (e.g. USFS, BLM). If private land was surveyed list the owner's full name to indicate that you did not trespass.

Map Elevation: The elevation of the site as indicated by the topographic map in feet (avoid using elevations from a GPS)

Datum: The map datum used (typically NAD 27 if off topographic map or WGS84 if off GPS unit on standard setting).

UTM Zone: Universal Transverse Mercator zone recorded on the topographic map.

UTM East: Universal Transverse Mercator easting coordinate in meters as recorded on the topographic map or GPS receiver. Be sure to note any major differences between UTM coordinates on the map and those on the GPS receiver.

UTM North: Universal Transverse Mercator northing coordinate in meters as recorded on the topographic map or GPS receiver. Be sure to note any major differences between UTM coordinates on the map and those on the GPS receiver.

\section{Survey Information}

Date: Use MM-DD-YY format (e.g. 05/12/00 for May 12 of 2000).

Observers: List names or initials of individuals involved with survey of this site and circle the name of the recorder.

Begin Time: List the time the survey began in 24-hour format.

End Time: List the time the survey ended in 24-hour format.

Total Person Minutes of Search: Record the total person minutes the site was searched (e.g. if one person surveys for 15 minutes and another surveys for 30 minutes, but takes 5 minutes to measure a specimen the total person minutes is 40 minutes).

Area $\left(\mathbf{M}^{2}\right)$ Searched: Area in square meters that was surveyed.

Percent of Site Searched: Circle the appropriate category.

Percent Slope: Percent slope of site. Enter range if variable.

Aspect: Circle primary aspect of the site.

Habitat Type: Circle the appropriate habitat type.

Primary Canopy Species: List the major plant species in the canopy (e.g., red cedar, western hemlock, grand fir, ninebark)

Overall Percent Canopy Cover: Circle the appropriate category for total canopy cover.

Canopy Species Average DBH: Circle the appropriate category.

Photo Frame Number(s) / Descriptions: The number of the photo as viewed on the camera's view screen and a description of the contents of the photograph (e.g., $\# 13=1 \mathrm{x}$ Oreohelix strigosa and \#14-18 $=5 \mathrm{x}$ habitat). Take photos of all portions of the site and anything else that may be of interest (e.g., millipedes, potential site threats).

Weather: Circle weather condition during survey.

Air Temp: Record air temperature in ${ }^{\circ} \mathrm{C}$ at chest height in the shade. ${ }^{\circ} \mathrm{C}=\left({ }^{\circ} \mathrm{F}-32\right) / 1.8$

Soil Temp: Record soil temperature in ${ }^{\circ} \mathrm{C}$ at $10 \mathrm{~cm}$ depth. ${ }^{\circ} \mathrm{C}=\left({ }^{\circ} \mathrm{F}-32\right) / 1.8$

Soil Moisture: Circle the appropriate category.

Rock Type: Circle the appropriate category; note specific type if known.

Habitat Threats: Note impacts from grazing, logging, mining, flooding, road building, weeds, fire, etc.

Species Information

For each species, record the genus name and species, if known. If species cannot be identified in the field, place a brief description of their morphology here. Record the number alive and dead, and size range for individuals encountered, and time at first detection for the first individual encountered (e.g., 2 x 15 mm diameter (shells) or TL=80-90mm (slugs): @ 10 minutes). Record the tissue number or range of tissue numbers for tissue samples collected (see tissue collection protocols). Record the preliminary museum voucher specimen number and description for voucher specimens collected (see voucher specimen collection protocols). Circle the substrate the animal was associated with at time of detection. Record the presence of other species detected at the site (e.g., millipedes), the time at first detection, and the voucher number and description of animals collected (see voucher and tissue collection protocols). 


\section{Appendix C. USFS Northern Region Survey Sites in 2007 FOR LAND MOLlusks}





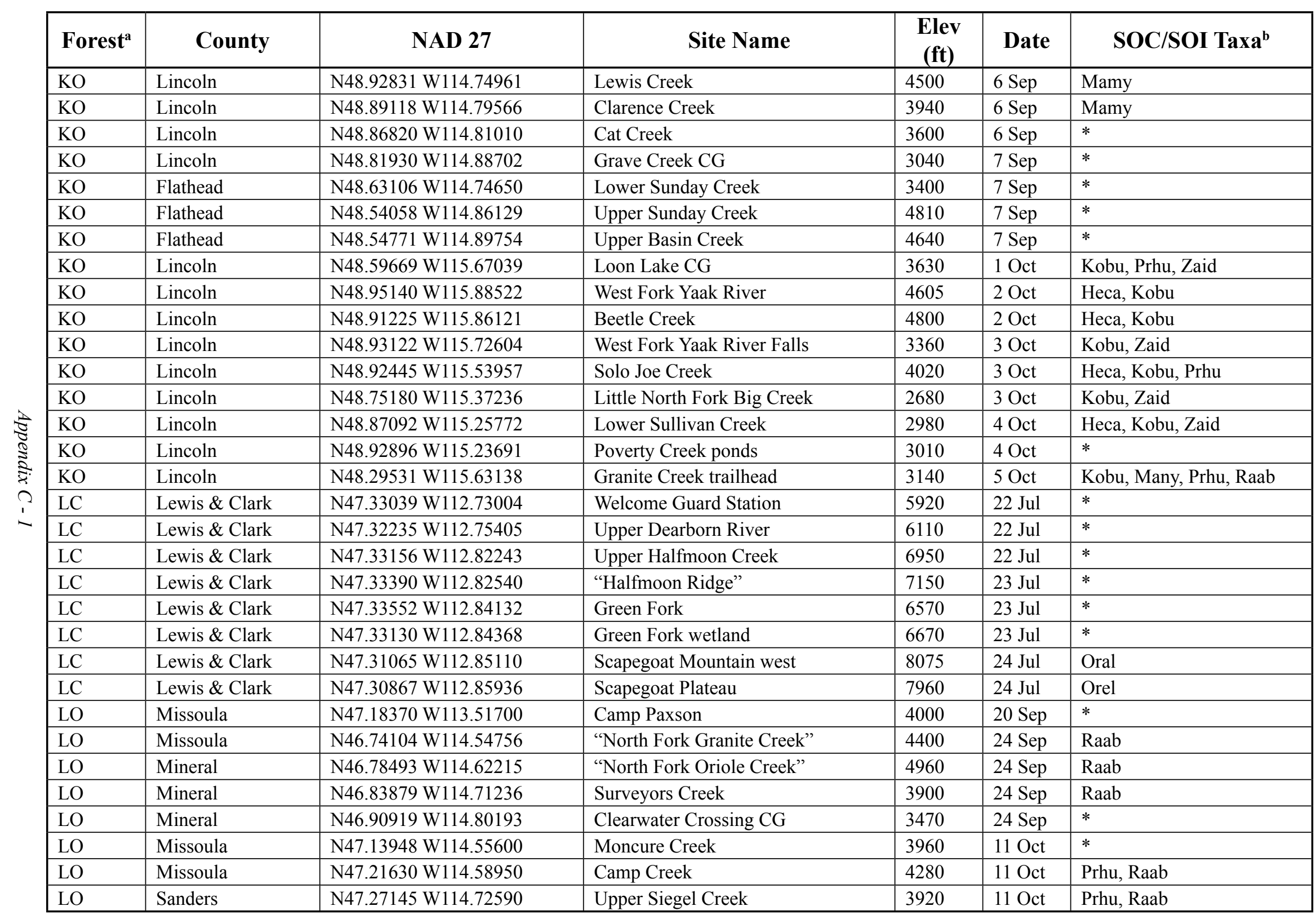




\begin{tabular}{|l|l|l|l|l|l|l|}
\hline Forest $^{\mathbf{a}}$ & \multicolumn{1}{|c|}{ County } & \multicolumn{1}{|c|}{ NAD 27 } & Site Name & $\begin{array}{c}\text { Elev } \\
(\mathbf{f t})\end{array}$ & \multicolumn{1}{|c|}{ Date $^{\text {SOC/SOI Taxa }^{\mathbf{b}}}$} \\
\hline LO & Missoula & N47.25455 W114.73360 & Eustache Creek & 4640 & 11 Oct & Prhu, Udly \\
\hline LO & Mineral & N47.28139 W115.34135 & Upper Ward Creek & 4100 & 13 Oct & Heda, Kobu, Mamy, Popo \\
\hline
\end{tabular}

${ }^{a}$ National Forests: KO (Kootenai), LC (Lewis and Clark), LO (Lolo).

b * = only non SOC/SOI mollusks detected; SOC/SOI taxa codes: Heca (Pale Jumping-slug, Hemphillia camelus), Heda (Marbled Jumping-slug, Hemphillia danielsi), Kobu (Pygmy Slug, Kootenai burkei), Mamy (Magnum Mantle-slug, Magnipelta mycophaga), Oral (Alpine Mountainsnail, Oreohelix alpina), Orel (Carinate Mountainsnail, Oreohelix elrodi), Popo (Humped Coin, Polygyrella polygyrella), Prhu (Smoky Taildropper, Prophysaon humile), Raab (Fir Pinwheel, Radiodiscus abietum), Udly (Lyre Mantleslug, Udosarx lyrata), Zaid (Sheathed Slug, Zacoleus idahoensis 


\section{Appendix D. Observations of the Scapegoat Mountainsnails (OREOHELIX)}





\section{OBSERVATIONS OF THE SCAPEGOAT MOUNTAINSNAILS (OREOHELIX)}

During an ascent of Scapegoat Mountain (9202 ft elevation) on 24 July 2007 (Rocky Mountain RD, Lewis and Clark National Forest) by Hendricks and companions, and explorations of the Scapegoat Plateau about 1.0-1.5 miles west of the summit (7800-8100 ft elevation), two species of mountainsnail (Oreohelix) were found in barren limestone alpine terrain in the basin (cirque) draining north into Green Fork creek. Collections of shells and live animals were made in the field for later determination, but the two species appeared to represent the Alpine Mountainsnail (Oreohelix alpina) and the Carinate Mountainsnail (Oreohelix elrodi), or an undescribed form closely related to Oreohelix elrodi.

Surprisingly, of the 12 sites occupied by snails and searched for at least 20 minutes, $O$. alpina and $O$. elrodi were present at half each (shells and live individuals at all sites) but both species were never found together, nor did the areas of occurrence for both species overlap (i.e., apparently no area of sympatry). This result is statistically significant (Fisher Exact Test, $\mathrm{P}=0.0137$ ) assuming equal probability of finding one and two species at an occupied site. O. alpina was found in talus sites under loose rocks about 1.01.25 miles west of the summit of Scapegoat Mountain (Figures D1-D4), whereas $O$. elrodi was present in talus and more stable rocky sites under rocks 1.25-1.5 miles west of the summit (Figures D5-D8). The full extent of occurrence for both species on the Scapegoat Plateau remains unknown, because only the central region of the plateau was searched, and investigation of this area was very incomplete.

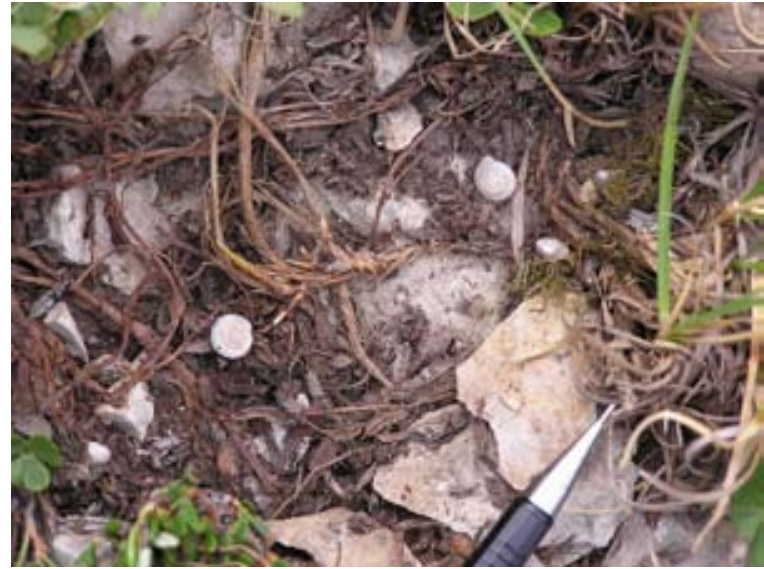

Figure D1. Alpine Mountainsnail (Oreohelix alpina) on 24 July 2007 in situ under limestone block at about $8000 \mathrm{ft}$ on the Scapegoat Plateau.

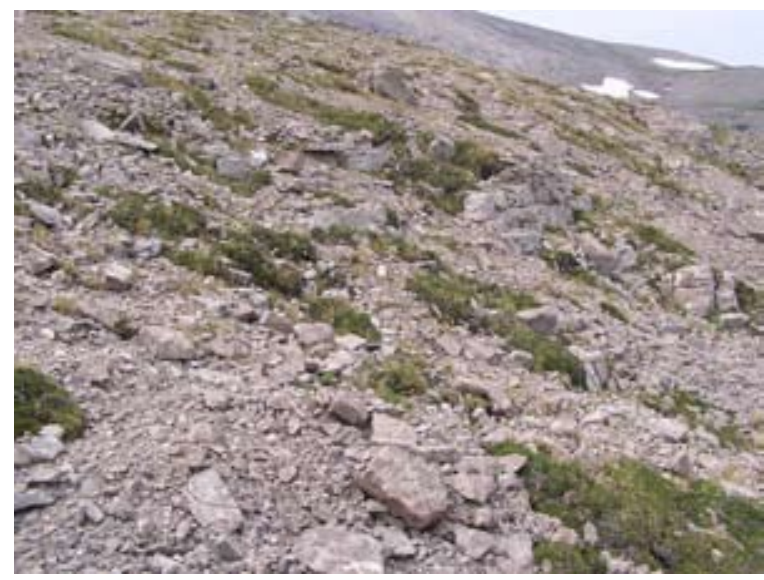

Figure D3. Local habitat typical of sites occupied by the Alpine Mountainsnail on the Scapegoat Plateau.

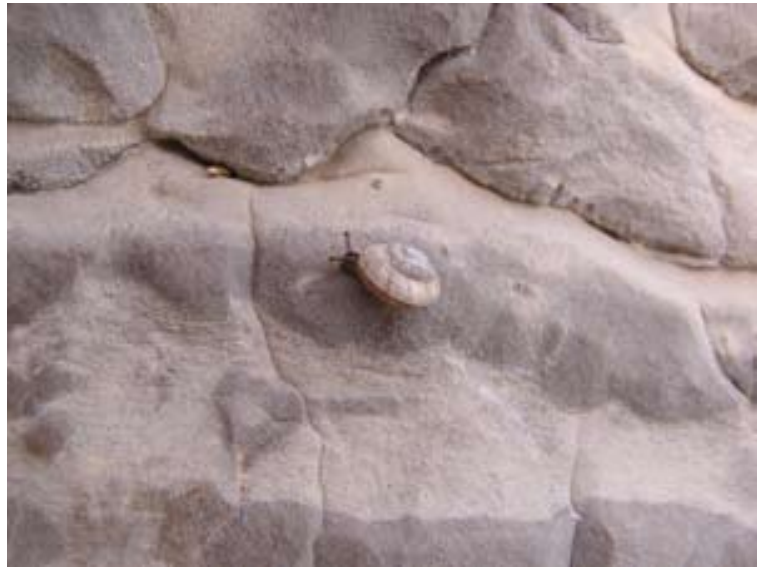

Figure D2. Alpine Mountainsnail on the underside of a limestone block.

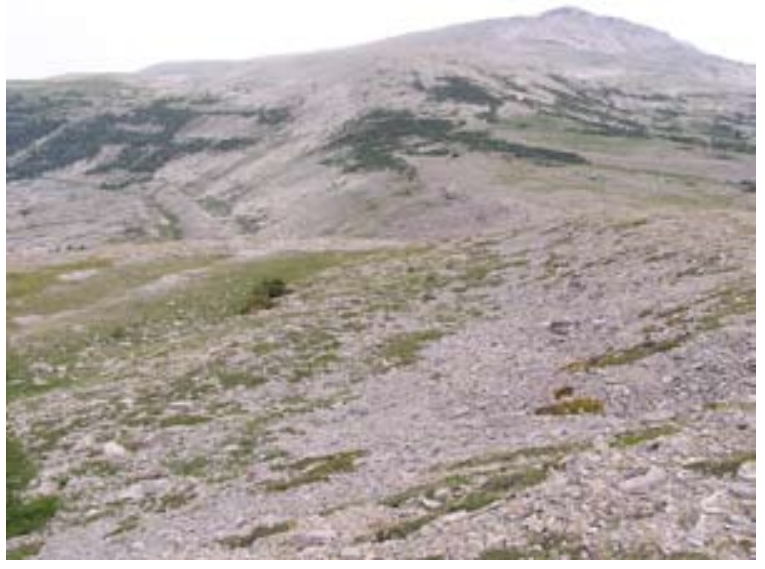

Figure D4. Landscape view from $8000 \mathrm{ft}$ of the Scapegoat Plateau where Alpine Mountainsnails were found. Summit of Scapegoat Mountain (9202 ft) in the background. 


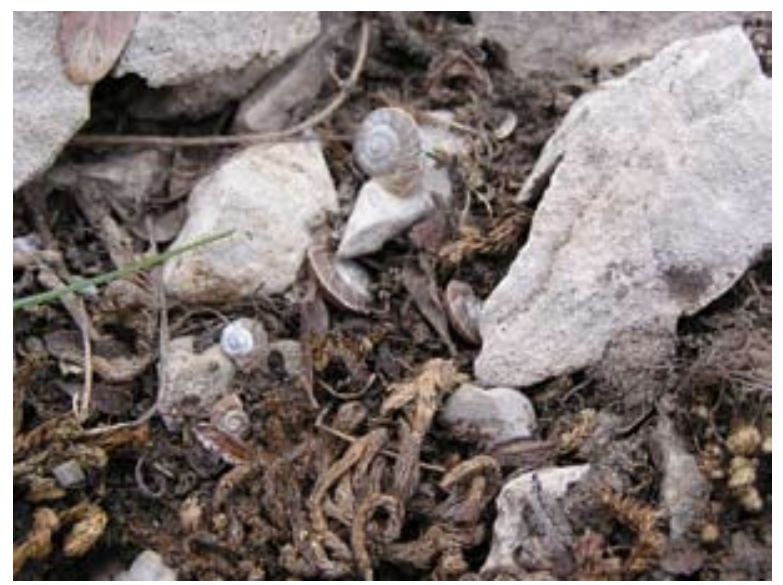

Figure D5. Carinate Mountainsnail (Oreohelix elrodi) on 24 July 2007 in situ under limestone block at about $7900 \mathrm{ft}$ on the Scapegoat Plateau.

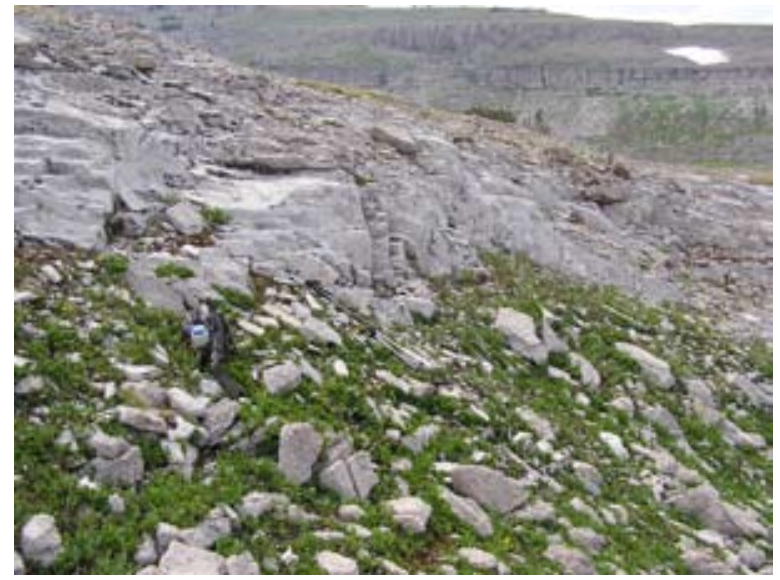

Figure D7. Local habitat typical of sites occupied by the Carinate Mountainsnail on the Scapegoat Plateau.

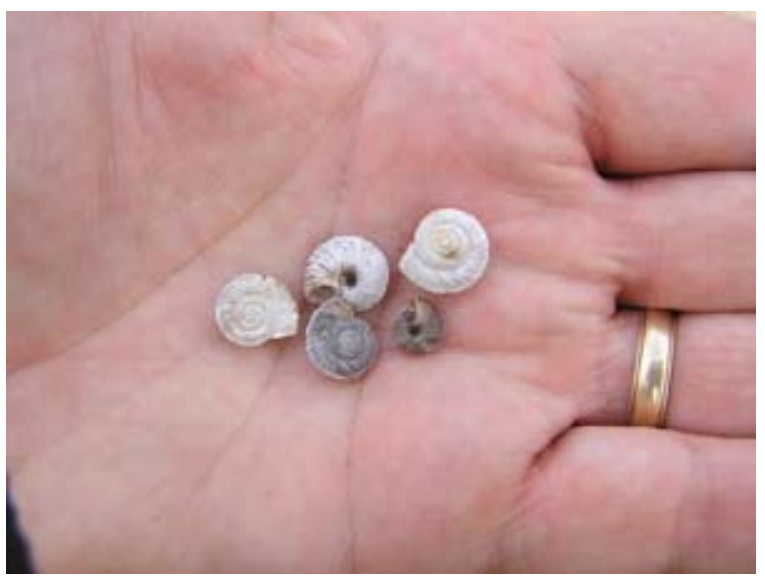

Figure D6. Carinate Mountainsnails.

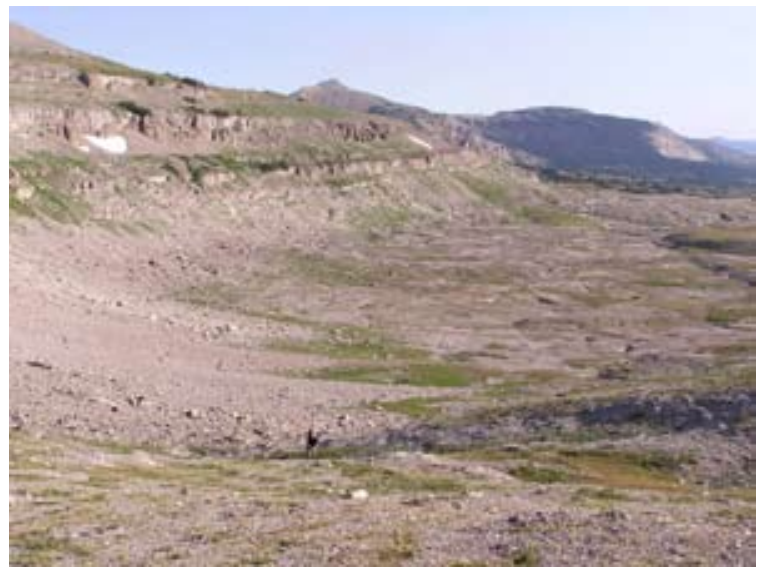

Figure D8. Landscape view from $8000 \mathrm{ft}$ of the Scapegoat Plateau where Carinate mountainsnails were found. Occupied sites were along the margins of the relatively flat basin in the center-right of the photograph.

\section{Alpine Mountainsnail (Oreohelix alpina)}

Preliminary analysis of morphological data show shell diameter and height of the Scapegoat Oreohelix alpina are consistent with shell morphology data from the other known locations for the Alpine Mountainsnail in the Mission and Swan ranges to the west (Table D1; see also Elrod 1903b; Hendricks 1998; Fairbanks 2002). Mean values for shell traits of the Swan Range individuals are larger than for the Scapegoat and Mission specimens because of a lack of immature animals in the Swan Range sample.

Table D1. Shell morphology for Oreohelix alpina from three Montana mountain ranges. HD is the ratio of height divided by diameter. Values are means (SD); range.

\begin{tabular}{|l|c|c|c|}
\hline Variable & Scapegoat Plateau (62) & Mission Mountains (17) & Swan Range (10) \\
\hline Diam (mm) & $7.7(1.4) ; 2.4-11.7$ & $7.4(2.1) ; 2.6-9.6$ & $9.7(1.0) ; 8.5-11.3$ \\
\hline Height (mm) & $4.6(0.8) ; 1.4-7.0$ & $4.1(1.3) ; 1.3-5.2$ & $5.4(0.5) ; 4.9-6.4$ \\
\hline HD & $0.6(0.04) ; 0.5-0.7$ & $0.5(0.03) ; 0.5-0.6$ & $0.6(0.3) ; 0.5-0.6$ \\
\hline No. whorls & $3.9(0.5) ; 1.6-4.6$ & $3.6(0.6) ; 2.0-4.1$ & $4.1(0.2) ; 3.8-4.3$ \\
\hline
\end{tabular}

Plotting shell height against shell diameter shows a relatively linear relationship for the combined sample from all three mountain ranges (Figure D9), with no obvious areas of segregation in the samples. 


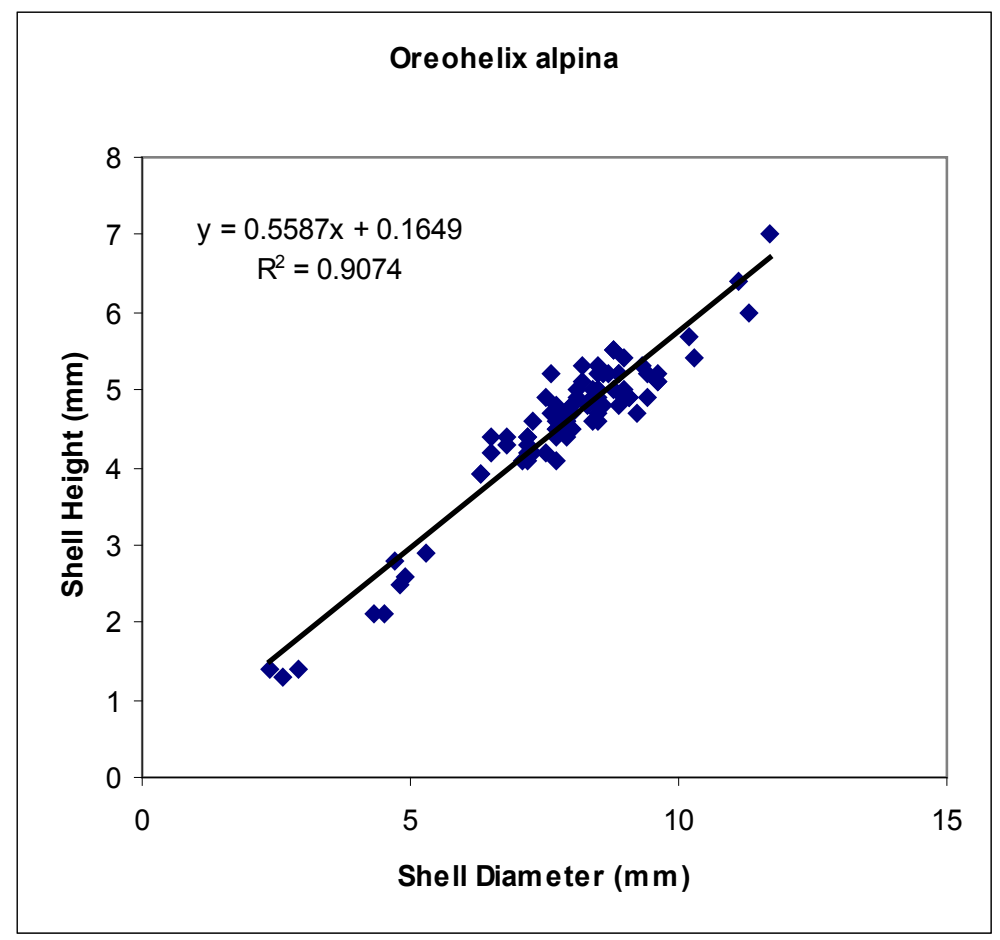

Figure D9. Relationship of shell height to shell diameter for the Alpine Mountainsnail (Oreohelix alpina). Sample includes specimens from the Scapegoat Plateau (62), Mission Mountains (17), Swan Range (10).

\section{Carinate Mountainsnail (Oreohelix elrodi)}

Preliminary analysis of morphological data show shell diameter and height of the Scapegoat Oreohelix elrodi are much smaller than shells from the other known locations for the Carinate Mountainsnail in the Mission and Swan ranges to the west (Table D2; see also Elrod 1903a; Fairbanks 1984; Hendricks 1998). Mean values for shell traits of individuals from the Mission Mountains and Swan Range are larger than for the Scapegoat, in part because of a lack of immature animals in the Missions sample, but also because no animals found on the Scapegoat Plateau exceeded $15 \mathrm{~mm}$ diameter whereas 27 of 36 from the combined Mission/Swan sample exceeded this value. Lack of larger individuals in the Scapegoat sample does not appear to be an artifact of sampling. Over 500 shells on the Scapegoat Plateau were encountered, and the largest individuals were collected from each site where they were present. Presence of few small animals in the combined Mission/Swan sample, however, indicates under-sampling of that size class.

Table D2. Shell morphology for Oreohelix elrodi from three Montana mountain ranges. HD is the ratio of height divided by diameter. Values are means (SD); range.

\begin{tabular}{|l|c|c|c|}
\hline Variable & Scapegoat Plateau (51) & Mission Mountains (20) & Swan Range (16) \\
\hline Diam (mm) & $10.5(2.5) ; 3.2-14.7$ & $18.0(9.7) ; 9.7-22.7$ & $14.4(7.8) ; 3.1-23.7$ \\
\hline Height (mm) & $4.7(1.1) ; 1.5-6.4$ & $8.7(1.7) ; 4.5-11.4$ & $7.1(4.1) ; 1.4-12.7$ \\
\hline HD & $0.5(0.3) ; 0.4-0.5$ & $0.5(0.03) ; 0.4-0.6$ & $0.5(0.04) ; 0.4-0.6$ \\
\hline No. whorls & $3.7(0.5) ; 1.8-4.5$ & $4.7(0.4) ; 3.7-5.3$ & $4.1(1.3) ; 2.1-5.5$ \\
\hline
\end{tabular}

There are at least two possibilities explaining why the Scapegoat Oreohelix elrodi are physically smaller than individuals from other populations. First, the alpine habitat occupied by this species on the Scapegoat Plateau is unlike that of the other populations in the Mission and Swan ranges, where occupied talus slopes are well below treeline and imbedded in a matrix of trees and shrubs (Hendricks 1998; Hendricks 2003). Furthermore, the rocky substrate is different; the Scapegoat population was found amongst lime- 
stone talus, while the species is found in diorite or argillite talus in the Missions and Swans. Thus, a more favorable climate and habitat in the Missions and Swans could favor a larger average adult body size.

Second, the Scapegoat Oreohelix is not $O$. elrodi but a closely related undescribed taxon. As mentioned above, it's presence above treeline in limestone terrain is unlike that for other known populations of $O$. elrodi. At the very least, the Scapegoat population could represent a distinct subspecies of $O$. elrodi, and the description of such could be justified on the basis of shell morphology alone.

We prefer a conservative approach until genetic and anatomical studies can be completed on the Scapegoat population and contrasted with the Mission Mountains and Swan Range populations. The relationship of shell height to shell diameter of a sample using individuals from all three mountain ranges is linear, suggesting the Scapegoat population is on the same growth trajectory as the other populations (Figure D10). Thus, although gene flow is no longer occurring between these populations, they could still be morphologically and genetically indistinguishable, as is the case with widespread populations of Oreohelix cooperi in eastern Montana and the Black Hills of Wyoming and South Dakota (Weaver et al. 2006; Anderson and Schmidt 2007; Anderson et al. 2007).

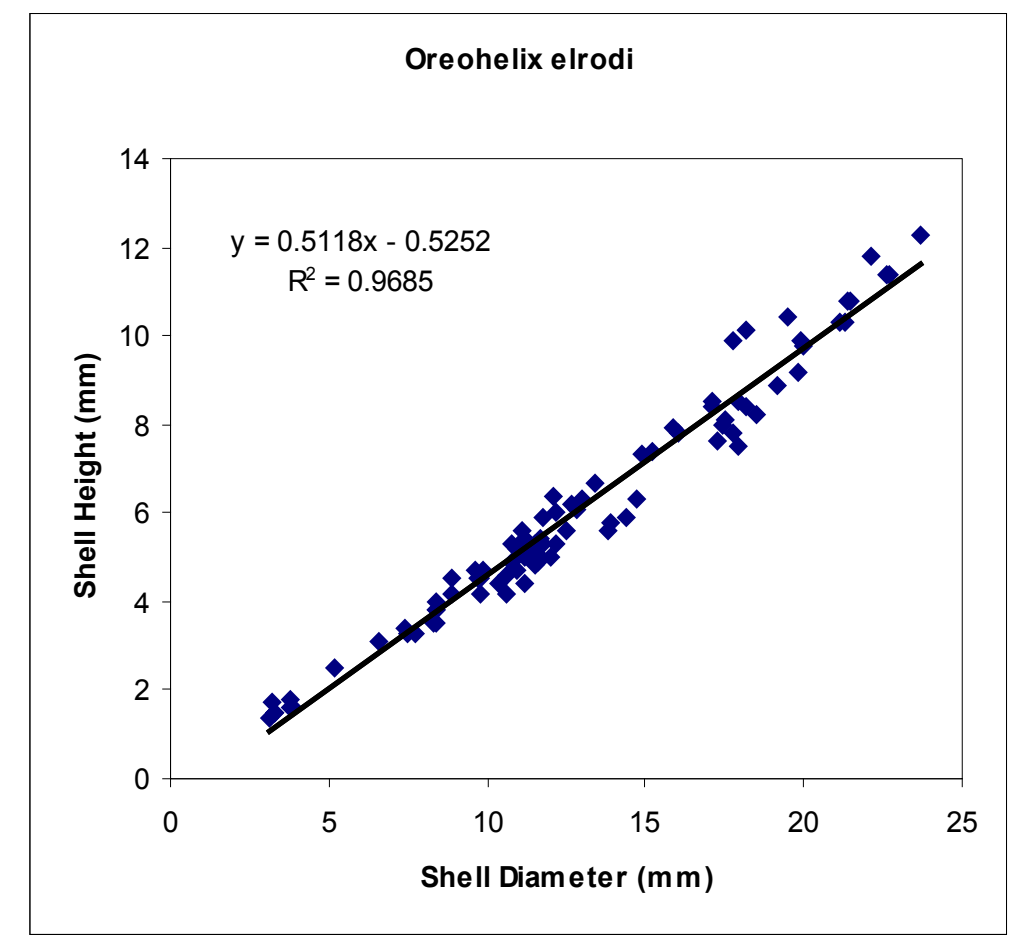

Figure D10. Relationship of shell height to shell diameter for the Carinate Mountainsnail (Oreohelix elrodi). Sample includes specimens from the Scapegoat Plateau (51), Swan Range (16), and Mission Mountains (20). 


\section{Appendix E. Predicted Distribution Models for Northern Region Land Mollusks}





\section{INTRODUCTION}

This appendix gives background information on the modeling effort. Model output for all terrestrial mollusks is posted under the individual species accounts on the online Montana Field Guide at: http://fieldguide.mt.gov/

Despite recent survey efforts during the 2005 through 2007 field seasons, observation records for terrestrial mollusks in Montana are very limited for most species (Table A1). Due to the lack of observation records, predicted distribution models were created in order to: (1) better understand the potential ranges of species in Montana; (2) identify areas of predicted distribution that should be targeted for future surveys; (3) determine which environmental variables have the highest predictive association with presence of individual species; and (4) identify spatial patterns in the suitability of habitat for these species.

\section{Modeling Approach}

Program Maxent Version 2.3 (Jaynes 1957; Miroslav et al. 2004, 2005, 2007; Phillips et al. 2004, 2006; www.cs.princeton.edu/ schapire/maxent/) was used to create statewide predicted distribution models based on locations of observations for individual species in the statewide Point Observation Database and 6 continuous (elevation, slope, landsurface curvature, annual precipitation, maximum July temperature, minimum January temperature) and 5 categorical (aspect, geology, 1992 National Land Cover Data, soil temperature class, STATSGO soils) environmental layers. Observation locations for each species were input in comma delimited format and environmental layers were fitted to 90 meter grid cell pixels in ASCII format. Both species observation locations and environmental layers were projected to North American Datum 1983 in Montana State Plane.

Program Maxent Version 2.3 (Jaynes 1957; Miroslav et al. 2004, 2005, 2007; Phillips et al. 2004, 2006; www.cs.princeton.edu/ schapire/maxent/) generates probability distributions for all environmental layers over all pixels that are associated with observations of the species. These environmental "features" are used to constrain the probability distribution computed to predict the statewide distribution of species so that estimated distributions match characteristics of the empirical distributions resulting from the positive data. Depending on the amount of positive data available the estimated distribution is automatically constrained to match the empirical average (linear feature), average and variance (quadratic feature), covariance (product feature), proportional occurrence (threshold feature), or average below and constant above a certain point (hinge feature). Categorical environmental variables have a discrete feature for every possible value of the variable so that the estimated distributions have the same proportional representation of each categorical value. In practice Maxent 2.3 avoids overfitting of models to the training data by "regularizing" or relaxing the feature constraints so that feature expectations only have to be close to the empirical distributions rather than exactly equal to them. A regularization parameter can be entered in Maxent 2.3 in order to delineate just how close of a fit is needed between empirical features and estimated distributions.

Maxent makes use of the Gibbs distribution which takes the form:

$\mathrm{P}(\mathrm{x})=\exp (\mathrm{c} 1 * \mathrm{f} 1(\mathrm{x})+\mathrm{c} 2 * \mathrm{f} 2(\mathrm{x})+\mathrm{c} 3 * \mathrm{f} 3(\mathrm{x}) \ldots) / \mathrm{Z}$

Where $\mathrm{c} 1, \mathrm{c} 2, \mathrm{c} 3, \ldots$ are weighted constants, $\mathrm{f} 1, \mathrm{f} 2, \mathrm{f} 3, \ldots$ are the constrained environmental features, and $\mathrm{Z}$ is a scaling constant that ensures that $\mathrm{P}$ sums to 1 over all grid cells. The Maxent 2.3 algorithm is guaranteed to converge to values of $\mathrm{c} 1, \mathrm{c} 2, \mathrm{c} 3, \ldots$ that give the unique optimum distribution $\mathrm{P}$, and, therefore, the outputs are deterministic. The program begins with a uniform distribution (the distribution with maximum entropy) and successively modifies each weighted constant on each iteration until either the change 
in the "gain" (the log of the number of grid cells minus the average of the negative log probabilities of the sample locations) falls below a set threshold or a set maximum number of iterations are performed. Thus, the Maxent 2.3 algorithm finds the most uniform distribution (the one with the maximum entropy) subject to the constraints of the environmental features. Maxent 2.3 can use every grid cell that has values for all the environmental variables to calculate the distribution. However, because there are a large number of 90-meter grid cells for Montana (10,204 columns and 5,892 rows), and the modeling performance of Maxent 2.3 does not improve significantly with very large numbers of pixels, 60,000 background pixels (added to those with positive species data) were used to represent the variety of environmental conditions present in the data. This limitation also serves to generalize or "regularize" the model to make sure that it is not overfit to the limited number of locations where species were observed.

The main output is in the form of a cumulative function with grid cells having values of 100 representing the most suitable habitat (best fit to the positive data) while those with values closer to 0 are less suitable habitat (worst fit to the positive data). Note that Maxent Version 2.3 output is not interpreted as probability of occupancy. Other standard model output includes: (1) an evaluation of omission error rates for training and test data as a function of the cumulative threshold and overall predicted area. Note that all data available for terrestrial mollusks was used to train the models so there was insufficient data to independently test the models; (2) a Receiver Operating Characteristic (ROC) curve which evaluates the overall predictive power of the model; (3) a table of potential thresholds which could be used to categorize the continuous output into a binomial predicted or not predicted output; (4) a statewide map showing the continuous probability function as well as the training and test data points; (5) response curves for individual environmental variables showing how each affects the output while all other environmental variables are held constant at their average sample value; and (6) jackknife charts showing the relative importance of all environmental variables as a function of the fit of the model to the data with their exclusion or sole inclusion in the model.

Below we provide an overview of terrestrial mollusk observations used in the modeling effort as well as comments on the model output. We then describe the environmental input layers and go through an example interpretation of model outputs. Complete model output for individual species has been posted to individual species accounts on the online Montana Field Guide at: http://fieldguide.mt.gov/ 
Tablè 1. Overview of Terréstrial Mollük Obsērvatioñs Used in Modeling Effort ànd Model Cömment. Of the 58 terrestrial mollusks documented in Montana, 39 species had sufficient numbers of observation records for modeling their predicted distribution and of these, 11 had poor fitting models because they were based on very few records. The table below summarizes observation records for these species and provides a brief commentary on model limitations and model output. In general models performed well in terms of omission and commission error rates where positive data is present in a region. However, there is reason to believe that the models may perform less well in regions that lack surveys (i.e., they are probably over fit to regions that have positive data from surveys). All model output should be regarded as a first iteration with additional modeling needed (e.g., the exact characteristics of the soils and geology classes need to be identified when these variables are found to be driving the models

\begin{tabular}{|c|c|c|c|c|c|}
\hline $\begin{array}{c}\text { Scientific Name } \\
\text { (Bold }=\text { Species of Concern) }\end{array}$ & $\begin{array}{l}\text { G Rank / } \\
\text { S Rank }\end{array}$ & $\begin{array}{l}\text { Total } \\
\text { No. } \\
\text { Records }\end{array}$ & $\begin{array}{l}\text { No. Records } \\
\leq 400 \text { Meters } \\
\text { Locational } \\
\text { Uncertainty }\end{array}$ & $\begin{array}{c}\text { No. Spatially } \\
\text { Unique Records } \\
\text { Used to Train } \\
\text { Model } \\
\end{array}$ & Model Comments \\
\hline \multicolumn{6}{|l|}{ SNAILS } \\
\hline Allogona ptychophora & G5/S5 & 42 & 41 & 35 & $\begin{array}{l}\text { Model output indicates surveys are most needed in and around Glacier National Park } \\
\text { and Bitterroot drainages of Ravalli County. }\end{array}$ \\
\hline Anguispira kochi & G5/S5 & 87 & 87 & 74 & $\begin{array}{l}\text { Model output indicates surveys are most needed in and around Glacier National Park, } \\
\text { the South Fork of the Flathead River drainage and the Seeley/Swan area. }\end{array}$ \\
\hline Catinella rehderi & $\mathrm{G} 3 \mathrm{Q} / \mathrm{SNR}$ & 2 & 2 & 2 & $\begin{array}{l}\text { Model based on extremely small number of observation records. Model output } \\
\text { indicates surveys are most needed in the Big and Little Snowy, Judith, and Pryor } \\
\text { Mountains. }\end{array}$ \\
\hline Cochlicopa lubrica & G5/SNR & 1 & 1 & 0 & Not modeled due to limited number of observation records. \\
\hline Columella columella & G5/SNR & 2 & 2 & 2 & $\begin{array}{l}\text { Model based on extremely small number of observation records. Species likely went } \\
\text { undetected a number of survey sites due to its small size and low detection probability. }\end{array}$ \\
\hline Columella edentula & G5/SNR & 4 & 4 & 4 & $\begin{array}{l}\text { Model based on extremely small number of observation records. Species likely went } \\
\text { undetected a number of survey sites due to its small size and low detection probability. }\end{array}$ \\
\hline Cryptomastix mullani & $\mathrm{G} 4 / \mathrm{S} 4$ & 65 & 64 & 58 & $\begin{array}{l}\text { Model output indicates surveys are most needed in and around Glacier National Park, } \\
\text { the South Fork of the Flathead River drainage, the Seeley/Swan area, and the } \\
\text { Bitterroot drainages of Ravalli County. }\end{array}$ \\
\hline Discus brunsoni & G1/S1 & 9 & 4 & 1 & Not modeled due to limited number of observation records from same location. \\
\hline Discus shimekii & G5/S1 & 10 & 6 & 6 & $\begin{array}{l}\text { Model based on extremely small number of observation records. Model output } \\
\text { indicates surveys are most needed in southwest Montana. }\end{array}$ \\
\hline Discus whitneyi & G5/S5 & 113 & 113 & 110 & Species is clearly widespread. \\
\hline Euconulus fulvus & G5/S5 & 108 & 108 & 107 & Species is clearly widespread. \\
\hline Haplotrema vancouverense & G5/S1S2 & 11 & 10 & 10 & $\begin{array}{l}\text { Model output indicates surveys are most needed in Prospector Creek west of } \\
\text { Thompson Falls and Bitterroot drainages in Mineral County. }\end{array}$ \\
\hline Hawaiia minuscule & G5/SNR & 1 & 1 & 0 & Not modeled due to limited number of observation records. \\
\hline Microphysula ingersolli & G5/S5 & 88 & 88 & 81 & $\begin{array}{l}\text { Species is clearly widespread. Additional surveys in southwest Montana would seem } \\
\text { likely to detect their presence. }\end{array}$ \\
\hline Nesovitrea binneyana & G5/S5 & 41 & 41 & 37 & Species is clearly widespread. \\
\hline Nesovitrea electrina & G5/SNR & 1 & 1 & 0 & Not modeled due to limited number of observation records. \\
\hline Oreohelix alpina & G1/S1 & 9 & 7 & 9 & $\begin{array}{l}\text { Model output indicates surveys are most needed in and around Glacier National Park, } \\
\text { Mountains in the Bob Marshall Wilderness, and the Swan and Mission Mountain } \\
\text { Ranges. }\end{array}$ \\
\hline
\end{tabular}




\begin{tabular}{|c|c|c|c|c|c|}
\hline Oreohelix amariradix & G1G2/S1S2 & 8 & 5 & 3 & $\begin{array}{l}\text { Model based on extremely small number of observation records. Surveys conducted } \\
\text { in the Lolo Creek drainage are most likely to detect the species in new localities. }\end{array}$ \\
\hline Oreohelix carinifera & G1/S1 & 12 & 2 & 3 & $\begin{array}{l}\text { Model based on extremely small number of observation records. Model output } \\
\text { indicates surveys are needed on a variety of BLM and USFS lands in drier habitats } \\
\text { that have not yet been targeted for surveys. }\end{array}$ \\
\hline Oreohelix elrodi & G1/S1 & 28 & 6 & 6 & $\begin{array}{l}\text { Model based on small number of observation records. Model output indicates surveys } \\
\text { are most needed in and around Glacier National Park, in the Seeley/Swan region, and } \\
\text { portions of the South Fork of the Flathead River drainage. }\end{array}$ \\
\hline Oreohelix strigosa & G5/S5 & 40 & 39 & 39 & Species is clearly widespread. \\
\hline Oreohelix strigosa berryi & G5T2/S1S2 & 17 & 8 & 8 & $\begin{array}{l}\text { Model based on small number of observation records. Model output indicates surveys } \\
\text { are most needed in the Big and Little Snowy, Judith, Little Belt, Big Belt, eastern } \\
\text { Elkhorn and northern edge of the Beartooth Mountains. }\end{array}$ \\
\hline Oreohelix strigosa depressa & G5T5/SNR & 3 & 3 & 3 & $\begin{array}{l}\text { Model based on extremely small number of observation records. Species may best be } \\
\text { detected during surveys for other species. }\end{array}$ \\
\hline Oreohelix subrudis & G5/S5 & 49 & 48 & 48 & $\begin{array}{l}\text { Species is clearly widespread. Additional surveys in southwest Montana would seem } \\
\text { likely to detect their presence. }\end{array}$ \\
\hline Oreohelix yavapai & G5/SNR & 4 & 0 & 0 & Not modeled due to limited number of observation records. \\
\hline Oreohelix yavapai mariae & G4T1/S1 & 5 & 1 & 2 & $\begin{array}{l}\text { Model based on extremely small number of observation records. Model output } \\
\text { indicates surveys are most needed in selected portions of the Bridger, Tobacco Root, } \\
\text { Madison, and Gallatin Mountain Ranges. }\end{array}$ \\
\hline Polygyrella polygyrella & G3/S1S2 & 18 & 15 & 15 & $\begin{array}{l}\text { Model output indicates surveys are most needed in the Coeur d'Alene Mountains, the } \\
\text { Bitterroot Mountains of Mineral County, portions of the Cabinet Mountains, and the } \\
\text { area in and around Glacier National Park. }\end{array}$ \\
\hline Pristiloma arcticum & G3G4/SNR & 1 & 1 & 0 & Not modeled due to limited number of observation records. \\
\hline Punctum randolphi & G4/SNR & 3 & 3 & 3 & $\begin{array}{l}\text { Model based on extremely small number of observation records. Model output } \\
\text { indicates surveys are most needed in the Coeur d'Alene Mountains and the Bitterroot } \\
\text { Mountains of Mineral County. }\end{array}$ \\
\hline Pupilla hebes & G5/SNR & 1 & 1 & 0 & Not modeled due to limited number of observation records. \\
\hline Radiodiscus abietum & $\mathrm{G} 4 / \mathrm{S} 3 \mathrm{~S} 4$ & 79 & 65 & 57 & $\begin{array}{l}\text { Model output indicates surveys are most needed in the Mission Mountains, the area in } \\
\text { and around Glacier National Park, and the Bitterroot drainages in Ravalli County. }\end{array}$ \\
\hline Vallonia cyclophorella & G5/SNR & 5 & 5 & 5 & $\begin{array}{l}\text { Model based on small number of observation records. Species may best be detected } \\
\text { during surveys for other species. }\end{array}$ \\
\hline Vallonia gracilicosta & G5Q/S4S5 & 27 & 27 & 27 & $\begin{array}{l}\text { Species is clearly widespread. Model output indicates surveys are most needed in the } \\
\text { eastern Elkhorn Mountains, southern Big Belt Mountains, and near Bighorn Canyon. }\end{array}$ \\
\hline Vallonia pulchella & G5/SNR & 1 & 1 & 0 & Not modeled due to limited number of observation records. \\
\hline Vertigo cristata & G5/SNR & 1 & 1 & 0 & Not modeled due to limited number of observation records. \\
\hline Vertigo gouldii & G5/SNR & 2 & 2 & 2 & Very few records to base model on. \\
\hline Vertigo modesta & G5/S4S5 & 18 & 18 & 18 & $\begin{array}{l}\text { Species is clearly widespread. Species likely went undetected a number of survey } \\
\text { sites due to its small size and low detection probability. }\end{array}$ \\
\hline Vertigo ovata & G5/SNR & 1 & 1 & 0 & Not modeled due to limited number of observation records. \\
\hline Vitrina pellucida & G5/S5 & 111 & 111 & 111 & Species is clearly widespread. \\
\hline Zonitoides arboreus & G5/S5 & 157 & 151 & 151 & Species is clearly widespread. \\
\hline Zoogenetes harpa & G5/SNR & 1 & 1 & 0 & Not modeled due to limited number of observation records. \\
\hline
\end{tabular}




\begin{tabular}{|c|c|c|c|c|c|}
\hline Arion distinctus & G5/SNA & 1 & 1 & 0 & Not modeled. Exotic species with limited observations. \\
\hline Arion fasciatus & G5/SNA & 4 & 4 & 2 & Not modeled. Exotic species with limited observations. \\
\hline Arion intermedius & G5/SNA & 4 & 4 & 2 & Not modeled. Exotic species with limited observations. \\
\hline Arion rufus & G4G5/SNA & 5 & 5 & 5 & Not modeled. Exotic species with limited observations. \\
\hline Arion subfuscus & G5/SNA & 10 & 10 & 10 & Not modeled. Exotic species with limited observations. \\
\hline Deroceras laeve & G5/SNA & 40 & 40 & 38 & $\begin{array}{l}\text { Exotic species, but modeled because species appears to be widespread and its } \\
\text { interactions with native species may become important. }\end{array}$ \\
\hline Deroceras panormitanum & G5/SNA & 2 & 2 & 2 & Not modeled. Exotic species with limited observations. \\
\hline Deroceras reticulatum & G5/SNA & 7 & 7 & 7 & Not modeled. Exotic species with limited observations. \\
\hline Hemphillia camelus & G4/S1S2 & 11 & 11 & 7 & $\begin{array}{l}\text { Model based on small number of observation records. Model output indicates surveys } \\
\text { are most needed in Lincoln and southwestern Flathead Counties. }\end{array}$ \\
\hline Hemphillia danielsi & G2G3/S1S2 & 17 & 12 & 12 & $\begin{array}{l}\text { Model output indicates surveys are most needed in the area in and around Glacier } \\
\text { National Park and the Bitterroot Mountains in Mineral and Ravalli Counties. }\end{array}$ \\
\hline Kootenaia burkei & G2/S1S2 & 21 & 21 & 20 & $\begin{array}{l}\text { Model output indicates surveys are most needed in the area in and around Glacier } \\
\text { National Park and the Bitterroot Mountains in Mineral County, and the Seeley/Swan } \\
\text { area. }\end{array}$ \\
\hline Limax maximus & G5/SNA & 11 & 11 & 10 & Not modeled. Exotic species with limited observations. \\
\hline Magnipelta mycophaga & G3/S2S3 & 33 & 30 & 26 & $\begin{array}{l}\text { Model output indicates surveys are most needed in the area in and around Glacier } \\
\text { National Park, the Southfork of the Flathead drainage, the Bitterroot Mountains in } \\
\text { Mineral County, and the Seeley/Swan area. }\end{array}$ \\
\hline Prophysaon andersoni & G5/S1S2 & 7 & 7 & 6 & $\begin{array}{l}\text { Model based on small number of observation records. Model output indicates surveys } \\
\text { are most needed in the lower Clark Fork River, Bull River, and Lake Creek drainages. }\end{array}$ \\
\hline Prophysaon humile & G3/S2S3 & 46 & 45 & 44 & $\begin{array}{l}\text { Model output indicates surveys are needed in and around Glacier Nation Park, the } \\
\text { Seeley/Swan area, the Mission Mountains, the east Cabinet Mountains, and the } \\
\text { Bitterroot Mountains in Mineral County. }\end{array}$ \\
\hline Udosarx lyrata & G2/S1 & 9 & 6 & 7 & $\begin{array}{l}\text { Model output indicates surveys are needed in the Bitterroot Mountains in Mineral and } \\
\text { Ravalli Counties, and the area around the northern portions of the Flint Creek } \\
\text { Mountains. }\end{array}$ \\
\hline Zacoleus idahoensis & G3G4/S2S3 & 34 & 27 & 27 & $\begin{array}{l}\text { Model output indicates surveys are needed in the Bitterroot Mountains in Mineral } \\
\text { County and on the western edge of the Mission Mountains. }\end{array}$ \\
\hline
\end{tabular}




\section{DESCRIPTIONS OF ENVIRONMENTAL INPUT LAYERS}

Input environmental layers consisted of 6 continuous (elevation, slope, curvature of land surface, annual precipitation, maximum July temperature, minimum January temperature) and 5 categorical (aspect, geology, 1992 National Land Cover Data, soil temperature class, STATSGO soils) variables. These layers were tiled together, resampled, and converted to a statewide coverage of 90 meter grid cells in ASCII format with 10,204 columns and 5,892 rows projected to North American Datum 1983 in Montana State Plane. Each source environmental layer is described below and, where appropriate, links to metadata are provided.

\section{Aspect (Categorical)}

Calculated using the Aspect function in ArcMap 9.2 Spatial Analyst from the 10-meter National Elevation Dataset (NED) and resampled to 90 meters. See description of the elevation layer and the associated NED metadata link below. A brief summary of raster cell value descriptions for grid bearing values follows below.

$$
\begin{aligned}
& 0=\text { Flat } \\
& 1=\text { North }(337.5-22.5) \\
& 2=\text { Northeast }(22.5-67.5) \\
& 3=\text { East }(67.5-112.5) \\
& 4=\text { Southeast }(112.5-157.5) \\
& 5=\text { South }(157.5-202.5) \\
& 6=\text { Southwest }(202.5-247.5) \\
& 7=\text { West }(247.5-292.5) \\
& 8=\text { Northwest }(292.5-337.5)
\end{aligned}
$$

\section{Curvature of Land Surface (Continuous)}

Calculated using the Curvature function in ArcMap 9.2 Spatial Analyst from the 90-meter resampled grid resulting from the 10-meter National Elevation Dataset (NED). See description of the elevation layer and the associated NED metadata link below. Values are continuous from -50 (concave land surface) to +50 (convex land surface).

\section{Elevation (Continuous)}

The National Elevation Dataset (NED) is a 1/3 arc-second (10-meter) raster grid of decimal meter values assembled by the U.S. Geological Survey. Metadata on the 1/3 arc-second (10-meter) NED is at: http:// seamless.usgs.gov/products/3arc.php

\section{Geology (Categorical)}

A polygonal coverage of surficial geology available in a mixture of 1:100,000 and 1:250,000 scales from the Montana State Geologic Mapping Program at the Montana Bureau of Mines and Geology. Metadata on the state geology map is at: http:/www.mbmg.mtech.edu/gmr/gmr-statemap.asp

\section{Maximum July Temperature (Continuous)}

A polygonal coverage of estimated average maximum daily temperatures for July in degrees Fahrenheit, for the climatological period 1971-2000. Estimates are based on Parameter-elevation Regressions on Independent Slopes Model (PRISM) derived raster data which uses known point temperature data and a digital elevation model (DEM) to generate gridded estimates of annual, monthly and event-based climatic parameters. General information on the underlying PRISM data and the source data itself can be down- 
loaded from the Oregon Climate Service website at: http://www.ocs.orst.edu/prism/. The Montana data reprojected to Montana State Plane and resampled to a resolution of 600 meters representing 33 temperature ranges in degrees Fahrenheit is available at: http://nris.mt.gov/nsdi/nris/tmax $7100 . h t m l$

\section{Minimum January Temperature (Continuous)}

A polygonal coverage of estimated average minimum daily temperatures for January in degrees Fahrenheit, for the climatological period 1971-2000. Estimates are based on Parameter-elevation Regressions on Independent Slopes Model (PRISM) derived raster data which uses known point temperature data and a digital elevation model (DEM) to generate gridded estimates of annual, monthly and event-based climatic parameters. General information on the underlying PRISM data and the source data itself can be downloaded from the Oregon Climate Service website at: http://www.ocs.orst.edu/prism/. The Montana data reprojected to Montana State Plane and resampled to a resolution of 600 meters representing 33 temperature ranges in degrees Fahrenheit is available at: http://nris.mt.gov/nsdi/nris/tmin71_00.html

\section{National Landcover Data (Categorical)}

The 1992 National Land Cover Data Set is based on 30-meter Landsat Thematic Mapper imagery. A brief summary of raster cell value descriptions follows below. Metadata on this layer can be found at: http:// nris.mt.gov/nsdi/nris/nlcdgrid.html

$\begin{array}{ll}11 & \text { Open Water } \\ 12 & \text { Perennial Ice/Snow } \\ 21 & \text { Low Intensity Residential } \\ 22 & \text { High Intensity Residential } \\ 23 & \text { Commercial/Industrial/Transportation } \\ 31 & \text { Bare Rock/Sand/Clay } \\ 32 & \text { Quarries/Strip Mines/Gravel Pits } \\ 33 & \text { Transitional } \\ 41 & \text { Deciduous Forest } \\ 42 & \text { Evergreen Forest } \\ 43 & \text { Mixed Forest } \\ 51 & \text { Shrubland } \\ 61 & \text { Orchards/Vineyards/Other } \\ 71 & \text { Grasslands/Herbaceous } \\ 81 & \text { Pasture/Hay } \\ 82 & \text { Row Crops } \\ 83 & \text { Small Grains } \\ 84 & \text { Fallow } \\ 85 & \text { Urban/Recreational Grasses } \\ 91 & \text { Woody Wetlands } \\ 92 & \text { Emergent Herbaceous Wetlands }\end{array}$

\section{Annual Precipitation (Continuous)}

A polygonal coverage of annual precipitation in inches for the climatological period 1961-1990 based on source data from the National Weather Service Cooperative stations, Natural Resources Conservation Service SNOTEL stations, and local networks. Metadata on this layer can be found at: http://nris.mt.gov/ nsdi/nris/precip.html 


\section{STATSGO Soils (Categorical)}

State Soil Geographic data (STATSGO) is a polygonal coverage of general soil associations developed by the National Cooperative Soil Survey. The soil maps for STATSGO are compiled by generalizing more detailed soil survey maps. Map unit composition for a STATSGO map is determined by transecting or sampling areas and expanding the data statistically to characterize the whole map unit. Therefore, map units depict the dominant soils making up the landscape and often contain dissimilar soil types. The approximate minimum area delineated is 625 hectares (1,544 acres). Background information and metadata on STATSGO is available at: http://nris.mt.gov/nsdi/statsgo.pdf, http://nris.mt.gov/nsdi/nris/SS19.html, and http://dbwww.essc.psu.edu/doc/statsgo/statsgo_info.html. Definitions for the 694 map units used in the input can be downloaded as .dbf files along with a STATSGO shapefile for Montana at: http://nris. mt.gov/gis/gisdatalib/gisDataList.aspx?datagroup=statewide-regional\&searchTerms=statsgo

\section{Slope (Continuous)}

Percent slope (rise over run multiplied by 100) calculated using the Slope function in ArcMap 9.2 Spatial Analyst from the 10-meter National Elevation Dataset (NED) and resampled to 90 meters. See description of the elevation layer and the associated NED metadata link above.

\section{Soil Temperature Regime (Categorical)}

A generalized polygonal coverage of soil temperature regimes. A brief summary of raster cell value descriptions follows below. A glossary of relevant soil terminology can be found at: https://www.soils. org/sssagloss/. Metadata on this layer can be found at: http://soils.usda.gov/use/worldsoils/mapindex/str. $\underline{\mathrm{html}}$

1

2

3

4

5

6

7

8

9

10

11

12
Cryic/Udic

Frigid/Udic

Frigid/Typic Ustic

Cryic/Typic Ustic

Frigid/Aridic Ustic

Frigid Aquic

Frigid/Typic Xeric

Water

Cryic/Typic Xeric

Cryic/Aridic Ustic

Mesic/Ustic Aridic

Cryic/Udic Ustic 


\section{Example InTERPRetation OF Model OUtPut}

The main map output that we show is in the form of a hot-to-cold color map indicating the suitability of each grid cell as a function of the environmental variables at that grid cell (Figure E1). A high (hot) value of the function at a particular grid cell indicates that the grid cell is predicted to have suitable conditions for that species. Thus, grid cells having values of 100 represent the most suitable habitat (hot or best fit to the positive data) while those with values closer to 0 represent less suitable habitat (cold or worse fit to the positive data). Note that this output is not interpretable as the probability of a species' occupancy. Rather it is a continuous cumulative function with the cumulative value of a cell indicating the percentage of grid cells that have raw outputs from the Maxent exponential model that are the value of that cell or smaller. Perhaps the best interpretation of the cumulative output is in terms of the expected omission error rate (the rate at which observations occur in areas where the model does not predict them). Thus a cumulative value threshold of $\mathrm{X}$ would be expected to have an $\mathrm{X} \%$ omission error rate. Because most terrestrial mollusk species have very little data and because the main goals of this modeling effort were to identify high probability areas that currently lack observation information for individual species, we truncated the continuous function at a threshold that balances the probability of omission and commission error rates and show only two levels of model output (orange and red) that are predicted to have the most suitable habitat conditions for the species (Figure E1).

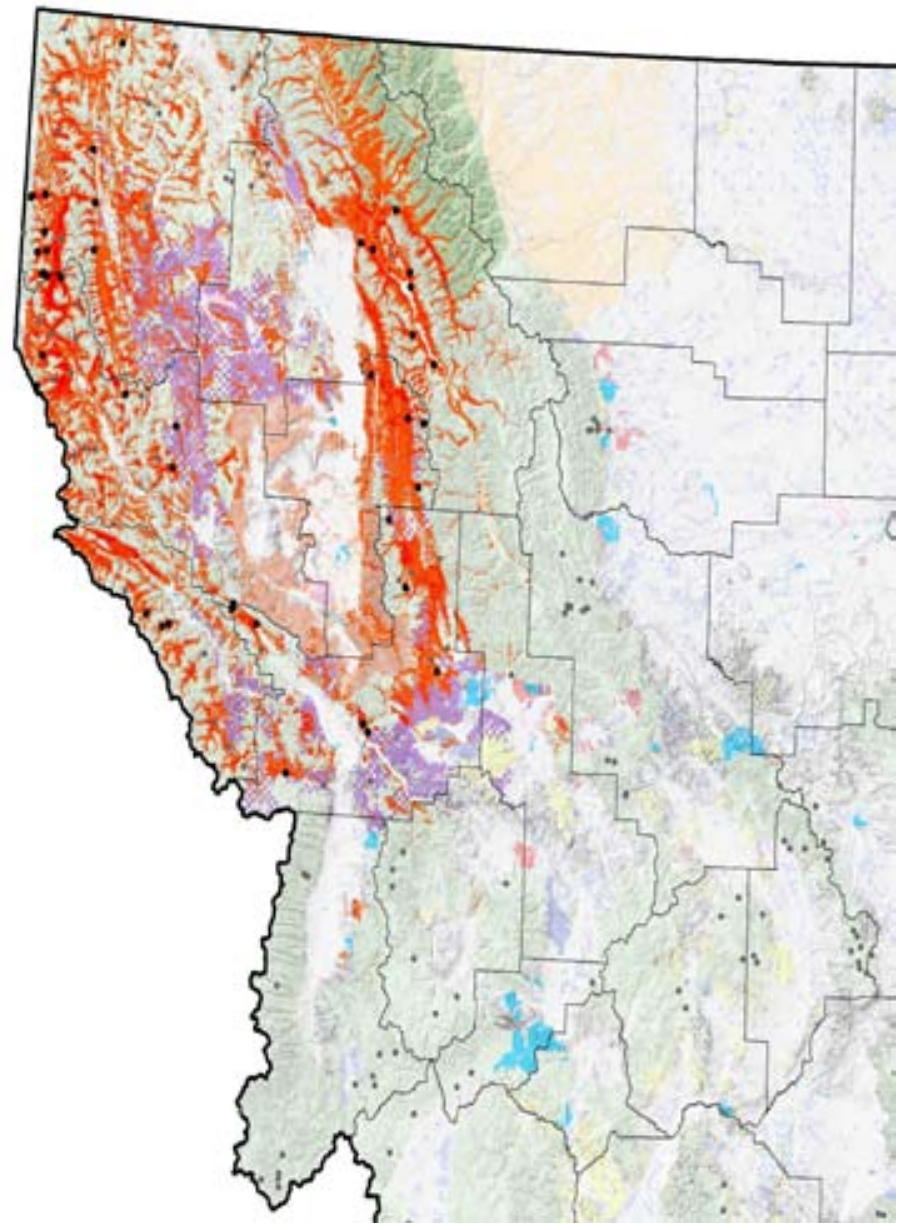

Figure E1. Predicted distribution model for Smoky Taildropper (Prophysaon humile). Hotter colors indicate areas that are predicted to have more suitable habitat for the species. Black dots are positive data used to build the model. Gray dots are locations where a timed visual encounter survey for terrestrial mollusks was performed during the 2005-2007 field seasons. Landownership, a shaded relief map, and county lines are included for reference. 


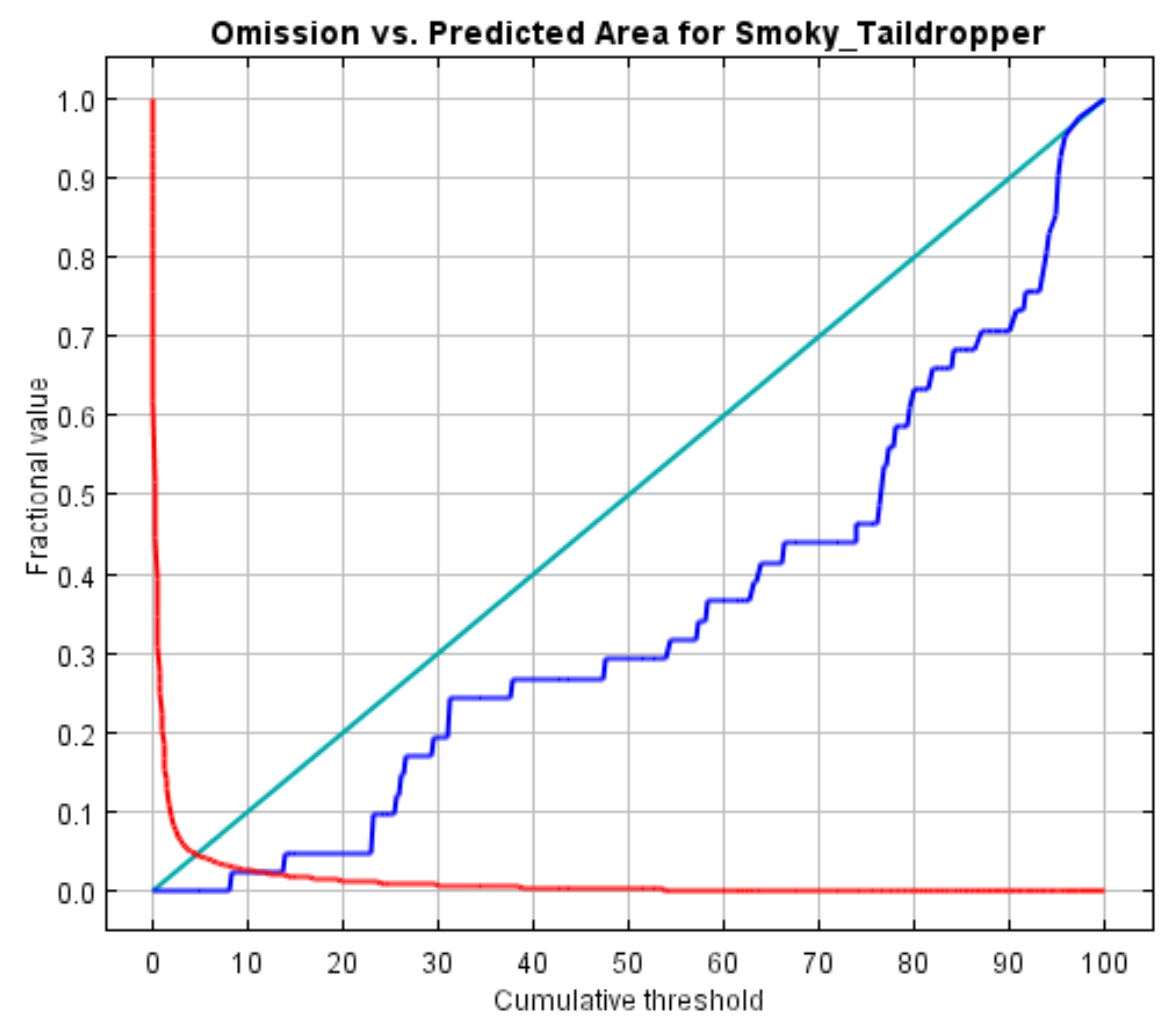

Fraction of background predicted Omission on training samples Predicted omission

Figure E2. An evaluation of omission error rates for training data as a function of the cumulative threshold and overall predicted area. Note that all data available for terrestrial mollusks was used to train the models so there was insufficient data to independently test the models. The red line indicates the overall fraction of the map area fitting each value of the cumulative threshold. Thus, for the Smoky Taildropper, about 70\% of Montana has a cumulative threshold near zero (i.e. no suitable habitat). The light blue line is the predicted omission rate for each cumulative threshold. Notice that the actual omission rate of training samples (dark blue line) is lower than the predicted omission rate with no omissions occurring until a cumulative threshold value of 8 and an overall fractional map area of 0.025 . 


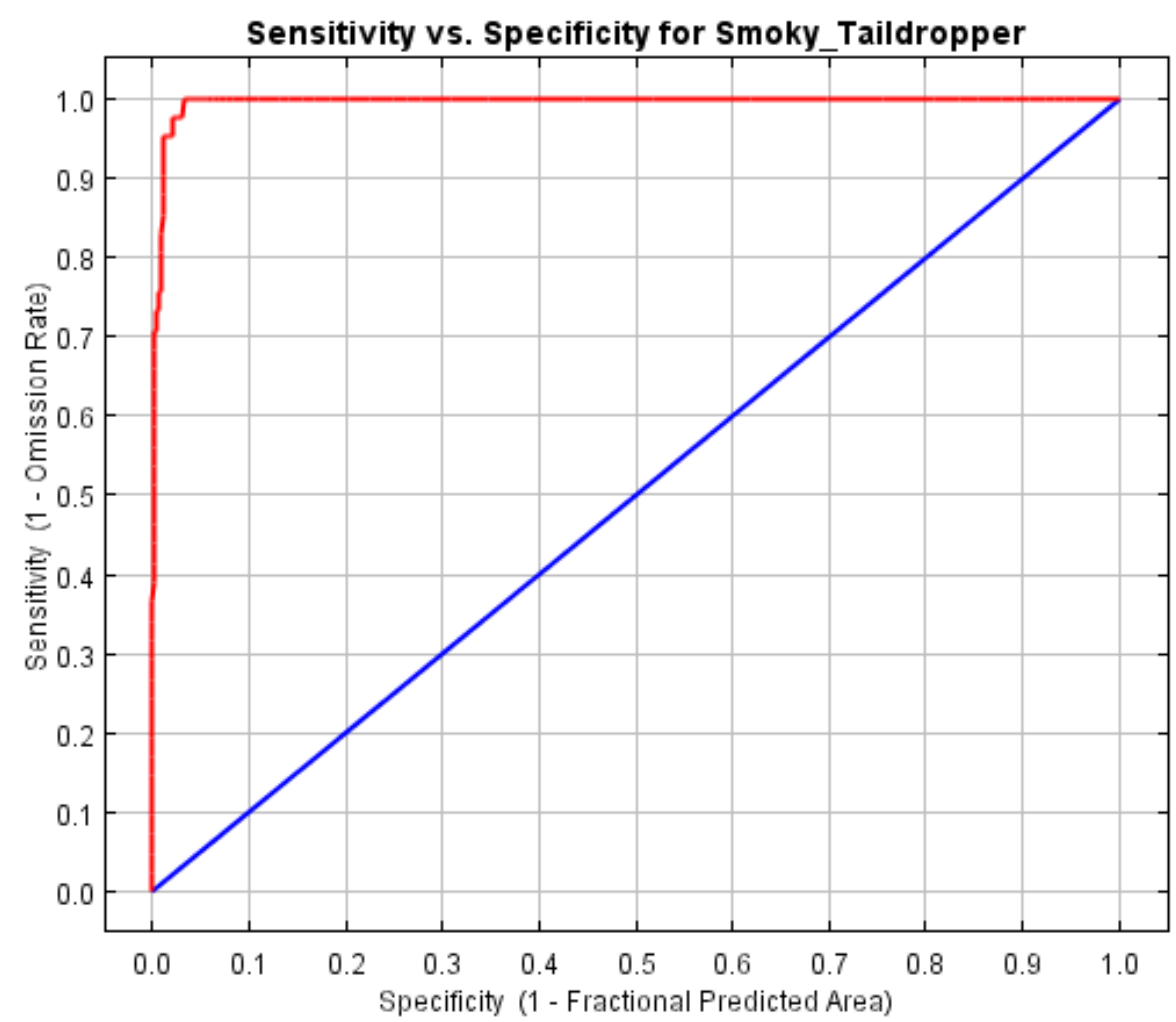

Training data $(\mathrm{AUC}=0.996)$ Random Prediction $(A \cup C=0.5)$

Figure E3. A Receiver Operating Characteristic (ROC) curve evaluating the overall predictive power of the model with the Area Under the Curve (AUC). The AUC value for the Smoky Taildropper model of 0.996 indicates that when two random locations are chosen the model has a 99.6\% probability of assigning a higher cumulative threshold value to the location with more suitable habitat. The light blue line indicates how a neutral or random model would perform (i.e., it only has a 50\% probability of assigning a higher cumulative threshold value to a random location with more suitable habitat than a random location with less suitable habitat). The further toward the top left of the graph the red training data line is, the better the model is at predicting the presences contained in the training data. Sensitivity (plotted on the y-axis) is the proportion of positive locations that were correctly classified by the model. Sensitivity is also known as the true positive rate and can be thought of as the degree of absence of omission errors. Specificity is the proportion of random locations chosen from the background (these pseudo-absences are used instead of true negative locations) that were correctly classified by the model as negative. One minus the Specificity (plotted on the $x$-axis) is known as the false positive rate and represents the commission error rate. Thus, the Smoky Taildropper model below has a high absence of omission errors and a low occurrence of commission errors. 

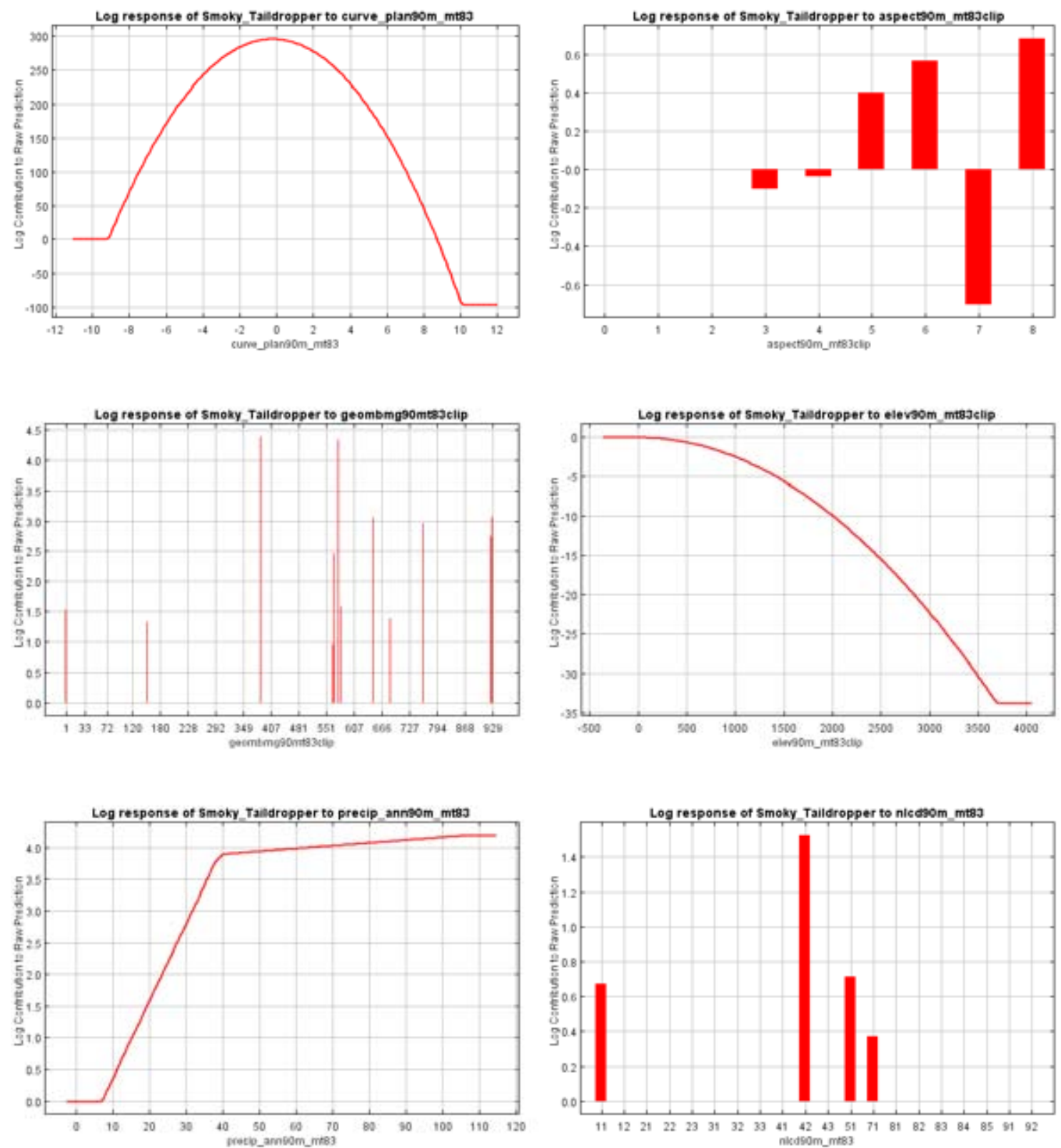

Figure E4. Response curves for individual environmental variables showing how the logistic prediction changes as each environmental variable is varied while all other environmental variables are held constant at their average sample values. The value on the $y$-axis is predicted probability of suitable conditions as given by the logistic formula $P(x)=\exp (c 1 * f 1(x)+c 2 * f 2(x)+$ $c 3 * f 3(x) \ldots) / Z$. Note that if any of the environmental variables are correlated, the marginal response curves can be misleading (e.g., two highly correlated variables with opposite response curves could effectively cancel each other out). Value definitions for categorical variables are either shown in the descriptions of the environmental variables or can be accessed via the metadata links provided. 

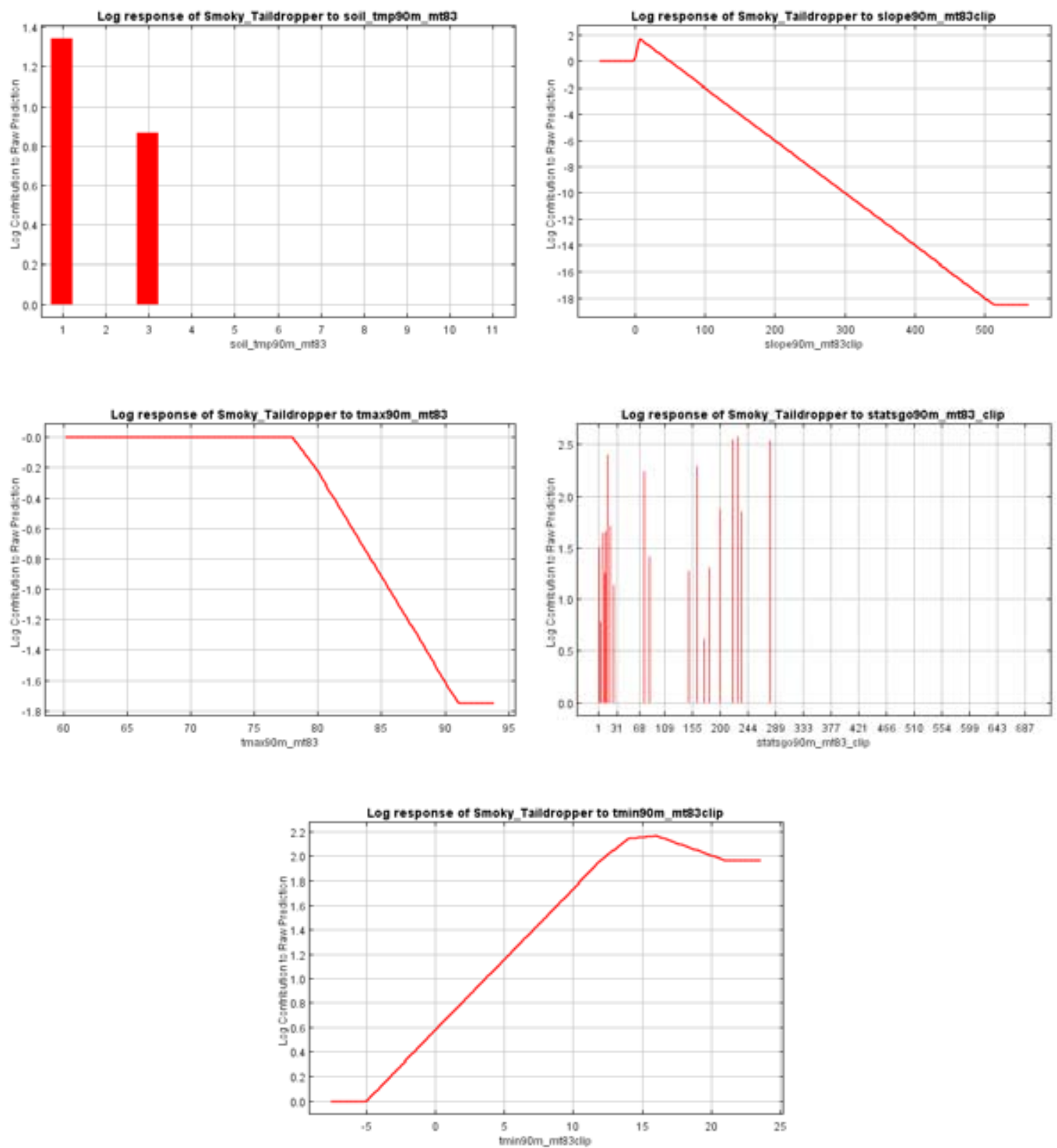

Figure E4. (Continued). Response curves for individual environmental variables showing how the logistic prediction changes as each environmental variable is varied while all other environmental variables are held constant at their average sample values. The value on the $y$-axis is predicted probability of suitable conditions as given by the logistic formula $P(x)=\exp (c 1 * f 1(x)+c 2$ $* f 2(x)+c 3 * f 3(x) \ldots) / Z$. Note that if any of the environmental variables are correlated, the marginal response curves can be misleading (e.g., two highly correlated variables with opposite response curves could effectively cancel each other out). Value definitions for categorical variables are either shown in the descriptions of the environmental variables or can be accessed via the metadata links provided. 


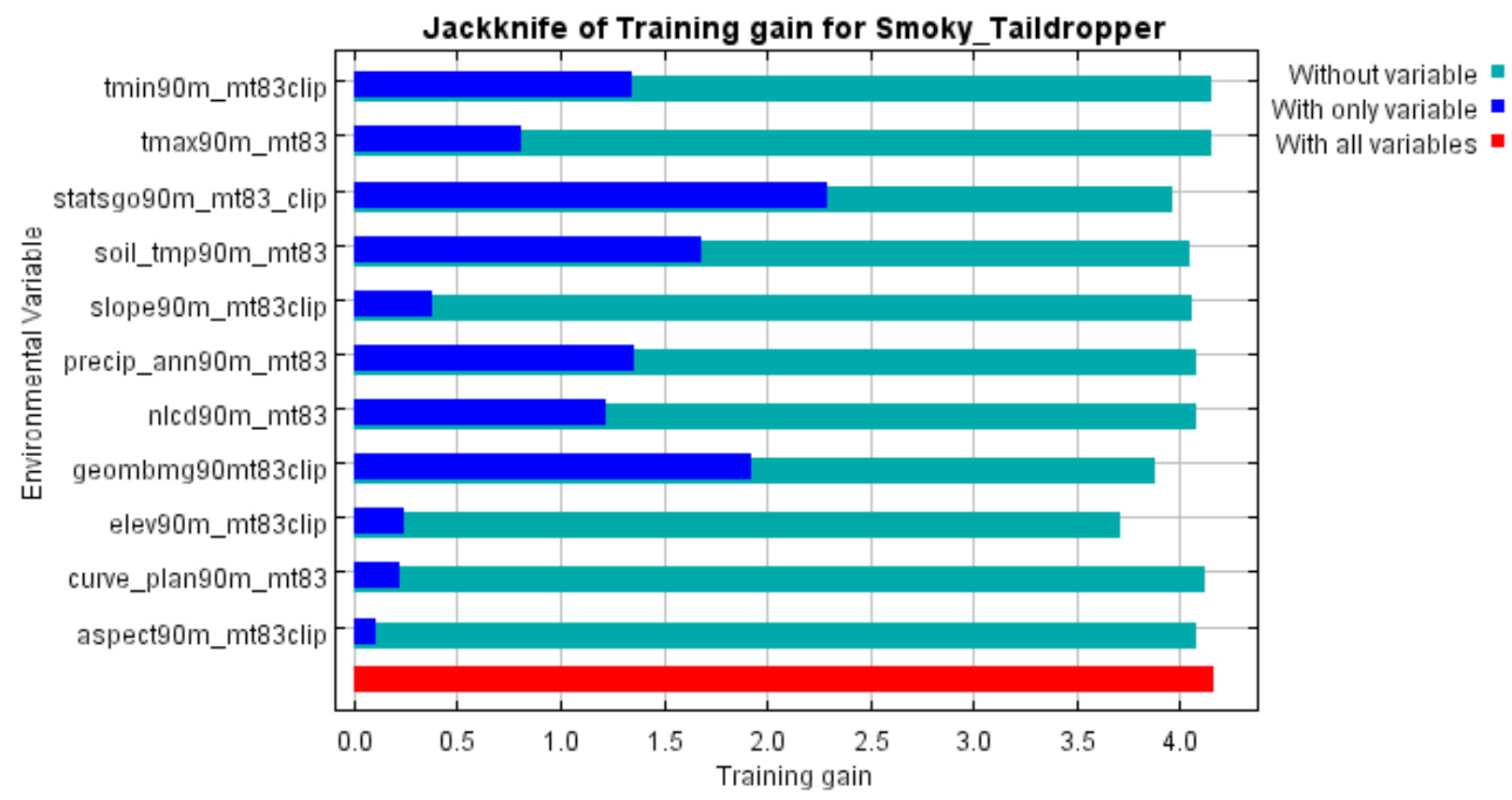

Figure E5. Jackknife chart showing the relative importance of environmental variables as a function of the change in "gain" (the log of the number of grid cells minus the average of the negative log probabilities of the sample locations) resulting from the exclusion or sole inclusion of the environmental variable in the model. Variables with the highest training gain resulting from sole inclusion of those variables (dark blue bars) are the best individual variables at describing suitable habitat for the species. Variables with the greatest reduction in training gain resulting from their exclusion (light blue bars) contain information on the species habitat use that is not present in other variables. The red bar indicates the maximum gain achieved with inclusion of all variables. 
REFERENCES (most can be downloaded at: www.cs.princeton.edu/ sschapire/maxent/)

Jaynes, E. T. 1957. Information theory and statistical mechanics. Physics Reviews 106:620-630.

Miroslav, D., S.J. Phillips, and R.E. Schapire. 2004. Performance guarantees for regularized maximum entropy density estimation. Proceedings of the Seventeenth Annual Conference on Computational Learning Theory pp. 472-486.

Miroslav, D., S.J. Phillips, and R.E. Schapire. 2007. Maximum entropy density estimation with generalized regularization and an application to species distribution modeling. Journal of Machine Learning Research 8 (2007): 1217-1260.

Miroslav, D., R.E. Schapire, and S.J. Phillips. 2005. Correcting sample selection bias in maximum entropy density estimation. pp 323-330. In: Advances in Neural Information Processing Systems 18. MIT Press.

Phillips, S.J., R.P. Anderson, and R.E. Schapire. 2006. Maximum entropy modeling of species geographic distributions. Ecological Modelling 190(3-4):231-259.

Phillips, S.J., D. Miroslav, and R.E. Schapire. 2004. A maximum entropy approach to species distribution modeling. Proceedings of the Twenty-First International Conference on Machine Learning pp. $655-662$. 